\title{
Key enzymes and proteins of crop insects as candidate for RNAi based gene silencing
}

\author{
Vijaya Sudhakara Rao Kola ${ }^{\dagger}$, P. Renuka ${ }^{\dagger}$, Maganti Sheshu Madhav* and \\ Satendra K. Mangrauthia *
}

Department of Biotechnology, Directorate of Rice Research, ICAR-Indian Institute of Rice Research, Hyderabad, India

\section{OPEN ACCESS}

Edited by:

Raman Chandrasekar,

Kansas State University, USA

Reviewed by:

Chantal Dauphin-Villemant

Université de Lausanne, Switzerland

Paul Kenneth Witting

The University of Sydney, Australia

*Correspondence:

Maganti Sheshu Madhav and

Satendra K. Mangrauthia,

Department of Biotechnology,

Directorate of Rice Research,

ICAR-Indian Institute of Rice

Research, Rajendranagar,

Hyderabad-500 030, India

sheshu24@gmail.com;

skmdrr@gmail.com

${ }^{t}$ These authors have contributed equally to this work.

Specialty section:

This article was submitted to Integrative Physiology, a section of the journal

Frontiers in Physiology

Received: 14 November 2014 Accepted: 31 March 2015

Published: 22 April 2015

Citation:

Kola VSR, Renuka P, Madhav MS and Mangrauthia SK (2015) Key enzymes and proteins of crop insects as candidate for RNAi based gene silencing. Front. Physiol. 6:119. doi: 10.3389/fphys.2015.00119
RNA interference (RNAi) is a mechanism of homology dependent gene silencing present in plants and animals. It operates through 21-24 nucleotides small RNAs which are processed through a set of core enzymatic machinery that involves Dicer and Argonaute proteins. In recent past, the technology has been well appreciated toward the control of plant pathogens and insects through suppression of key genes/proteins of infecting organisms. The genes encoding key enzymes/proteins with the great potential for developing an effective insect control by RNAi approach are actylcholinesterase, cytochrome P450 enzymes, amino peptidase N, allatostatin, allatotropin, tryptophan oxygenase, arginine kinase, vacuolar ATPase, chitin synthase, glutathione-S-transferase, catalase, trehalose phosphate synthase, vitellogenin, hydroxy-3-methylglutaryl coenzyme A reductase, and hormone receptor genes. Through various studies, it is demonstrated that RNAi is a reliable molecular tool which offers great promises in meeting the challenges imposed by crop insects with careful selection of key enzymes/proteins. Utilization of RNAi tool to target some of these key proteins of crop insects through various approaches is described here. The major challenges of RNAi based insect control such as identifying potential targets, delivery methods of silencing trigger, off target effects, and complexity of insect biology are very well illustrated. Further, required efforts to address these challenges are also discussed.

Keywords: siRNA, off target, insecticide, resistance, dicer

\section{Introduction}

Insects are considered as the most significant biotic constraints affecting plants and animals life worldwide. Insects not only cause direct loss to agricultural production, but also indirectly as vectors for various plant pathogens. They belong to class Insecta or Hexapoda under the largest class of the major invertebrate phylum Arthropoda, with more than 30 orders (Gullan and Cranston, 2010; http://espacepourlavie.ca/en/chart-orders-insects).

The physiology of insects comprises several important biological systems such as digestive, circulatory, respiratory, muscular, endocrine, nervous and reproductive, which are governed by numerous proteins including enzymes. The digestive system comprises of three sections-foregut (stomodeam), midgut (mesenteron), and hindgut (proctodeam). Various enzymes are involved in the digestion process; e.g., amylase helps to break down carbohydrates, invertase breaks sucrose into monosaccharides, lipase digests lipids, pepsin, trypsin, chymotrypisin, carboxypeptidase digest proteins, and nucleases digest nucleic acids. Digestive proteinases inhibitors (especially serine PIs, 
cysteine PIs) have been effectively utilized for insect-control (Lehane and Billingsley, 1996). The circulatory system of insects doesn't possess well defined veins or arteries. Insect blood known as haemolymph flows freely through the body cavity and makes direct contact with organs and tissues (Chapman, 1998). It is involved in transports of hormones, nutrients, and wastes and plays important role in osmoregulation, temperature control, immunity, and skeletal function. Phenoloxidase enzyme is present throughout the body of insects including the open circulatory system of haemolymph (Reiko and Ashida, 1986). The phenoloxidase in insect haemolymph occurs as a proenzyme, prophenoloxidase which can be activated by an activator present in hemolymph and cuticle (Ashida et al., 1982). Circulatory system is known to play essential role in the molting process also (McGavin, 2001; Johnson and Triplehorn, 2005).

The respiratory system of insects resembles to other organisms as they exhale carbon dioxide, a waste product of cellular respiration. Oxygen is delivered to the cells directly through respiration, and not carried by blood (Hetz and Bradley, 2005). The basic unit of insect muscular system is the sarcomere that contains myofibrils inside the cytoplasm known as sarcoplasm. The covering membrane is the sarcolemma. Alpha-glycerophosphate dehydrogenase enzyme is important in the glycerophosphate cycle of insects flight muscle (Healy et al., 2004). The myosin heads are enzymes (ATPases) which interact with actin filaments to produce force and movement. Several key enzymes / proteins are involved in the insect reproductive system among which two enzymes namely angiotensin-converting enzyme (ACE) (Isaac et al., 1999) and juvenile hormone (JH) acid methyltransferase (JHAMT) are well studied in several insect species (Sparagana et al., 1985). Insects molting and metamorphosis are primarily under the control of two insect hormones, ecdysone and $\mathrm{JH}$ (Shinoda and Itoyama, 2003). Acetylcholinesterase (AChE) is an important enzyme in the central nervous system of insects. The important neurotransmitters such as acetylcholine and dopamine are released at synapses of nervous system to control the insects metabolism (Thany et al., 2010). Allatostatin and allatotropin are major insect neuropeptides which inhibit the biosynthesis of juvenile hormones (Lungchukiet et al., 2008; Abdel-latief and Hoffmann, 2014). Generally, insecticides control the insects by targeting crucial enzymes or proteins involved in different biological processes described above. Such insecticides have been classified based on their mode of action. Although, there are effective chemicals available for the control of insects, keeping in view of environmental pollution, ecological imbalance, and biohazard effects, it is necessary to find novel ways of insects control which includes RNA interference (RNAi) or RNA silencing.

RNA interference is a well described gene regulatory mechanism that controls the coding transcript level (mRNA) by either suppressing transcription (transcriptional gene silencing or TGS) or by activating a homology based mRNA degradation process (post-transcriptional gene silencing or PTGS) (Tomari and Zamore, 2005; Vaucheret, 2006; Agarwal and Mangrauthia, 2013). The process involves the production of double stranded RNAs (dsRNA) of target gene which is processed into 21-24 nt RNA duplexes by the RNase III enzyme dicer and its homologs (Zamore et al., 2000; Scott et al., 2013). These siRNAs are then incorporated into a multi-subunit endonuclease silencing complex called RNA-induced silencing complex (RISC). Argonaute proteins, the core catalytic components of RISC, use siRNA as a guide to recognize and degrade the complementary gene or mRNA (Hammond et al., 2000). Recent studies showed that transgenic plants harboring dsRNAs against insect target genes showed resistance/tolerance against insects, opening the way for a new generation of insect-resistant crops (Agarwal et al., 2012). The viable level of insect resistance (resistance of plants toward insects) can be achieved through RNAi by producing insect gene specific RNAi triggers; i.e., small interfering RNAs (siRNAs) or dsRNAs in transgenic plants (Price and Gatehouse, 2008). Among the protein based approaches, insecticidal proteins from the bacterium Bacillus thuringiensis (Bt) have been utilized to control some key pests through transgenic and non-transgenic methods in various crops. RNAi, an RNA based approach has great potential on crop protection against lepidopteron and coleopteran pests and likely to be taken up for applications where Bt based approaches have proven difficult, for example protection against flies (dipteran), and sapsucking homopteran pests (Ruiz-Medrano et al., 1999; Lucas et al., 2001). In order to achieve RNAi based insect resistance, several dsRNA/siRNA delivery methods have been developed to target key proteins/enzymes of insects (Yu et al., 2013).

Despite success of this technology, there are challenges that need to be addressed to make this more effective in coming years. Major concerns are developing efficient delivery methods and testing them in vivo through artificial diets, identification and characterization of RNAi machinery in insects, studying the off target effects on non-target organism, and durability of resistance. Further, more information on key proteins/enzymes involved in essential biological processes of insects would be important in insect control using RNAi. In spite of these concerns, there is no doubt that researchers and farmers have reasons to look forward to a new era of insect control (Gordon and Waterhouse, 2007).

\section{Key Enzymes of Insects}

The enzymes in insect's life cycle play central role in different biological processes such as digestive mechanism, defense mechanism, locomotion, feeding methods, temperature control, growth, and development etc. The list of such enzymes is given in Table 1.

\section{Key Regulatory and Structural Proteins of Insects}

Proteins are biological molecules imparting essential roles in insect growth and metabolism. In addition to their role as enzymes, structural, and regulatory proteins are also crucial to complete the life cycle of insects. Several insect proteins have been characterized and reported, few are listed in Table 2.

\section{Insecticides Targeting Key Proteins/Enzymes}

After the discovery of insecticidal activity of DDT and lindane, the first generation synthetic insecticides, the chemical 
TABLE 1 | Key enzymes and their role in insects life cycle.

\begin{tabular}{|c|c|c|c|c|}
\hline S.No & Enzyme name & Function & Location & References \\
\hline \multicolumn{5}{|c|}{ DIGESTIVE SYSTEM } \\
\hline 1 & Serine proteinases & $\begin{array}{l}\text { Proteolytic enzymes having a serine and a hsitidine in the } \\
\text { active site }\end{array}$ & Gut & Yan et al., 2001 \\
\hline 2 & Cysteine proteinases & Proteolytic enzymes having cysteine in the active site & Midgut & Koiwa et al., 2000 \\
\hline 3 & Aspartic proteinases & $\begin{array}{l}\text { Proteolytic enzymes hydrolyzing internal peptide bonds in } \\
\text { proteins }\end{array}$ & $\begin{array}{l}\text { Small intestine } \\
\text { (posterior midgut) }\end{array}$ & $\begin{array}{l}\text { Lehane and Billingsley, 1996; } \\
\text { Balczun et al., } 2012\end{array}$ \\
\hline 4 & Trypsin & $\begin{array}{l}\text { Proteolytic enzyme preferentially cleaves protein chains on } \\
\text { the carboxyl side of basic amino acids }\end{array}$ & $\begin{array}{l}\text { Gastric coeca and } \\
\text { midgut }\end{array}$ & Schoofs et al., 2002 \\
\hline 5 & Chymotrypsin & $\begin{array}{l}\text { Proteolytic enzyme that cleaves peptide amide bonds } \\
\text { where the aromatic amino acids are at carboxyl side }\end{array}$ & Midgut & Lehane and Billingsley, 1996 \\
\hline 6 & Amino peptidases & $\begin{array}{l}\text { Proteolytic enzymes hydrolyzing single amino acid from the } \\
\mathrm{N} \text {-terminus of the peptide chain }\end{array}$ & Midgutepithelium & $\begin{array}{l}\text { Lehane and Billingsley, 1996; } \\
\text { Sivakumar et al., } 2007\end{array}$ \\
\hline 7 & Carboxypeptidases & $\begin{array}{l}\text { Proteolytic enzymes hydrolyzing single amino acid from the } \\
\text { C-terminus of the peptide chain }\end{array}$ & Whole gut & $\begin{array}{l}\text { Lehane and Billingsley, 1996; } \\
\text { Bown and Gatehouse, } 2004\end{array}$ \\
\hline 8 & Collagenase & Endopeptidases that break the peptide bonds in collagen & Gut & Lecroise et al., 1979 \\
\hline 9 & Keratinases & Proteolytic enzymes that breakdown keratin protein & Midgut & Christeller et al., 1994 \\
\hline 10 & Elastases & Proteolytic enzymes that hydrolyse elastin protein & Midgut & Lehane and Billingsley, 1996 \\
\hline 11 & Amylases & $\begin{array}{l}\text { Enzymes that catalyze the hydrolysis of starch and other } \\
\text { polysaccharides }\end{array}$ & Midgut & Lehane and Billingsley, 1996 \\
\hline 12 & Glucosidases & $\begin{array}{l}\text { Enzymes that catalyze the hydrolysis of di- and } \\
\text { oligosaccharides }\end{array}$ & Midgut & $\begin{array}{l}\text { Swingle, 1925; Lehane and } \\
\text { Billingsley, } 1996\end{array}$ \\
\hline 13 & Maltase & $\begin{array}{l}\text { Enzyme that catalyzes the hydrolysis of the disaccharide } \\
\text { maltose }\end{array}$ & Midgut & Swingle, 1925 \\
\hline 14 & Invertase & Enzyme that catalyzes the hydrolysis of of sucrose & Midgut & Swingle, 1925 \\
\hline 15 & Cellulase & Enzyme that catalyzes the breakdown of cellulose & Gut & Fischer et al., 2013 \\
\hline 16 & Xylanase & Enzyme that catalyzes the hydrolysis of xylose & Gut & $\begin{array}{l}\text { Lehane and Billingsley, 1996; } \\
\text { Brennan et al., } 2004\end{array}$ \\
\hline 17 & Beta Glucanase & Enzyme that catalyzes the hydrolysis of glucan & Larval midgut & Bragatto et al., 2010 \\
\hline 18 & Lipases & Enzymes that catalyze the hydrolysis of fats (lipids) & Midgut & Swingle, 1925 \\
\hline \multicolumn{5}{|c|}{ DEFENSE } \\
\hline 19 & Catalase & $\begin{array}{l}\text { The antioxidant enzyme that converts } \mathrm{H}_{2} \mathrm{O}_{2} \text { to water and } \\
\text { oxygen }\end{array}$ & All tissues & Fraga et al., 2013 \\
\hline \multicolumn{5}{|c|}{ METABOLISM } \\
\hline 20 & Lactate dehydrogenase & Enzyme that catalyzes the lactic acid dehydrogenation & Insect muscles & Kitto and Briggs, 1962 \\
\hline 21 & Succinate dehydrogenase & Enzyme that catalyzes the succinic acid dehydrogenation & Insect muscles & Gorbachev et al., 2013 \\
\hline 22 & NADH oxidase & Oxidative enzyme involved in oxidation/ reduction & Respiratory tissues & Shappirio, 1974 \\
\hline 23 & $\begin{array}{l}\text { Succinate-cytochrome c } \\
\text { reductase }\end{array}$ & Oxidative enzyme involved in oxidation/ reduction & Respiratory tissues & Shappirio, 1974 \\
\hline 24 & NADH-cytochrome c reductase & Oxidative enzyme involved in oxidation/ reduction & Respiratory tissues & Shappirio, 1974 \\
\hline 25 & Pyruvate carboxylase & $\begin{array}{l}\text { Enzyme that catalyzes the ATP-dependent carboxylation of } \\
\text { pyruvate to oxaloacetate }\end{array}$ & All insect flight muscles & Crabtree et al., 1972 \\
\hline 26 & Hexokinase & Enzyme that catalyzes the phosphorylation of hexose & Insect muscles & Fraga et al., 2013 \\
\hline 27 & Protein phosphatase 5 (PP5) & Enzyme that catalyzes the de-phosphorylation of proteins & Almost in all tissues & Chen et al., 2014 \\
\hline 28 & $\begin{array}{l}\text { Cytochrome P450 enzymes } \\
\text { (CYPs) }\end{array}$ & $\begin{array}{l}\text { Group of enzymes involved in oxygenation, detoxification } \\
\text { processes, and synthesis and degradation of ecdysteroids } \\
\text { and juvenile hormones }\end{array}$ & $\begin{array}{l}\text { Virtually all insect } \\
\text { tissues }\end{array}$ & Feyereisen, 1999 \\
\hline 29 & Adenylate kinase & $\begin{array}{l}\text { Phosphotransferase enzyme that catalyzes the synthesis of } \\
\text { ATP }\end{array}$ & $\begin{array}{l}\text { Virtually all insect } \\
\text { tissues }\end{array}$ & Chen et al., 2012 \\
\hline 30 & Glycogen synthase & $\begin{array}{l}\text { Enzyme that catalyzes the conversion of glucose to } \\
\text { glycogen }\end{array}$ & Embryonic tissues & $\begin{array}{l}\text { Tang et al., 2012; Fraga et al., } \\
2013\end{array}$ \\
\hline 31 & Glycogen Phosphorylase & Enzyme that catalyzes the breakdown of glycogen & $\begin{array}{l}\text { Insect muscles and fat } \\
\text { bodies }\end{array}$ & $\begin{array}{l}\text { Steele, 1982; Tang et al., 2012; } \\
\text { Fraga et al., } 2013\end{array}$ \\
\hline 32 & Tyramine-mono-oxygenase & Enzyme that catalyzes the synthesis of the octopamine & Nervous tissues & Hess et al., 2008 \\
\hline 33 & $\begin{array}{l}\text { Juvenile hormone }(\mathrm{JH}) \text { acid } \\
\text { methyl-transferase }\end{array}$ & $\begin{array}{l}\text { Enzyme involved in reproduction diapause, and } \\
\text { polyphenisms }\end{array}$ & $\begin{array}{l}\text { All insect tissues } \\
\text { particularly in } \\
\text { reproductive tissues }\end{array}$ & Shinoda and Itoyama, 2003 \\
\hline 34 & Acetylcholinesterase & Enzyme that catalyzes the hydrolysis of the acetylcholine & Nervous tissues & Yang et al., 2010 \\
\hline 35 & Chitinase & Enzyme that catalyzes the hydrolysis of chitin & Molting fluids & $\begin{array}{l}\text { Arakane and Muthukrishnan, } \\
2010\end{array}$ \\
\hline
\end{tabular}


TABLE 2 | Key proteins and their function in insect life cycle.

\begin{tabular}{|c|c|c|c|c|}
\hline S.No & Protein & Insect & Function & References \\
\hline 1 & $\begin{array}{l}\text { Sensory neuron membrane } \\
\text { proteins -Apo1 }\end{array}$ & $\begin{array}{l}\text { Bombyx mori, Chilo } \\
\text { suppressalis }\end{array}$ & $\begin{array}{l}\text { Involved in pheromone specific olfactory sensory } \\
\text { mechanism }\end{array}$ & $\begin{array}{l}\text { Rogers et al., 2001; Liu et al., } \\
2013\end{array}$ \\
\hline 2 & Odorant binding proteins & $\begin{array}{l}\text { Loxostege sticticalis, Cydia } \\
\text { pomonella }\end{array}$ & $\begin{array}{l}\text { Involved in transporting semiochemicals across the } \\
\text { sensillum lymph to olfactory receptors }\end{array}$ & $\begin{array}{l}\text { Yin et al., 2012; } \\
\text { Ayme-Southgate et al., } 2013\end{array}$ \\
\hline 3 & Larval Hemolymph Protein (LHP) & Drosophila & Involved in larval development & Beverley and Wilson, 1982 \\
\hline 4 & Hexamerins & Spodoptera litura & Involved in metamorphosis and reproduction & Tang et al., 2010 \\
\hline 5 & $\begin{array}{l}\text { Lipophorin and lipid transfer } \\
\text { particle (LTP) }\end{array}$ & $\begin{array}{l}\text { Manduca sexta, Locusta } \\
\text { migratoria, Musca } \\
\text { domestica, Periplaneta } \\
\text { americana, Bombyx mori, } \\
\text { and Rhodnius prolixus }\end{array}$ & Involved in lipophorin function and transfer of lipids & Yokoyama et al., 2013 \\
\hline 6 & G proteins & Helicoverpa armigera & Involved in signaling & Hong-Hua et al., 2010 \\
\hline 7 & $\begin{array}{l}\text { Heat shock proteins (hsp90, } \\
\text { hsp70, and hsp60) }\end{array}$ & Chilo suppressalis & Involved in protein metabolism & Lu et al., 2014 \\
\hline 8 & Valine-rich midgut proteins & Manduca sexta & Involved in digestion of the plant diet & Odman-Naresh et al., 2013 \\
\hline 9 & $\begin{array}{l}\text { Peptidoglycan recognition } \\
\text { proteins (PGRPs) }\end{array}$ & $\begin{array}{l}\text { Culicidae (Armigeres } \\
\text { subalbatus) }\end{array}$ & Involved in recognition and binding of peptidoglycan & Wang et al., 2012 \\
\hline 10 & $\begin{array}{l}\text { Inhibitor of apoptosis protein } \\
\text { (IAP) }\end{array}$ & Spodoptera frugiperda & Involved in suppression of apoptosis & Huang et al., 2000 \\
\hline 11 & $\begin{array}{l}\text { Cuticle proteins (MsCP29) } \\
\text { (MsCP30/11) }\end{array}$ & Manduca sexta & Involved in molting & Csikos et al., 1999 \\
\hline 12 & Pupal cuticular proteins (CPs) & Tenebrio molitor & Involved in molting & Lemoine et al., 1993 \\
\hline 13 & $\begin{array}{l}\text { Cytoskeletal proteins zeelin1 and } \\
\text { zeelin2 }\end{array}$ & Lethocerus & Involved in formation of cytoskeleton & Ferguson et al., 1994 \\
\hline 14 & Kettin and projectin & $\begin{array}{l}\text { Bombyx mori Danaus } \\
\text { plexippus }\end{array}$ & Involved in high resting stiffness of indirect flight muscles & Ayme-Southgate et al., 2013 \\
\hline 15 & Collagen & Delia antiqua & Fibrous protein, involved in diapause & You-Jin et al., 2014 \\
\hline 16 & Sericin & Bombyx mori & Involved in growth of corneal cells & Chirila et al., 2013 \\
\hline 17 & Fibrion & Bombyx mori & Fibrous protein, involved in development of eye cell & Chirila et al., 2013 \\
\hline 18 & $\begin{array}{l}\text { Juvenile hormone binding protein } \\
\text { (JHBP) }\end{array}$ & Galleria mellonella & Involved in transport of hormone & Zalewska et al., 2009 \\
\hline 19 & Chorion proteins & Lepidopteran & Involved in formation of eggshell & Giannopoulos et al., 2013 \\
\hline 20 & $\begin{array}{l}\text { Vitelline membrane proteins } \\
\text { (VMPs) }\end{array}$ & $\begin{array}{l}\text { Bombyx mori, Manduca } \\
\text { sexta, Danaus plexippus, } \\
\text { Heliconius melpomene }\end{array}$ & Involved in membrane formation in egg shell & Xu et al., 2012 \\
\hline 21 & TGF-alpha-like protein & Drosophila & $\begin{array}{l}\text { Involved in establishment of anterior-posterior and } \\
\text { dorsal-ventral polarity through signal transduction } \\
\text { pathway }\end{array}$ & $\begin{array}{l}\text { Neuman-Silberberg and } \\
\text { Schüpbach, } 1996\end{array}$ \\
\hline 22 & Metallothioneins (MT) & Orchesella cincta & Involved in binding of heavy metals & Hensbergen et al., 2000 \\
\hline 23 & $\begin{array}{l}\text { Transferrin (GmmTsf1) and } \\
\text { Ferritin }\end{array}$ & Glossinidae (tsetse fly) & Involved in transport and metabolism of iron & $\begin{array}{l}\text { Strickler-Dinglasan et al., } \\
2006\end{array}$ \\
\hline 24 & Aquaporins & $\begin{array}{l}\text { Aedes aegypti Drosophila } \\
\text { melanogaster Polypedilum } \\
\text { vanderplanki } \\
\text { Cicadella viridis }\end{array}$ & Involved in transport of water molecules & Spring et al., 2009 \\
\hline 25 & Peritrophin & Holotrichia oblita & $\begin{array}{l}\text { Involved in protection of the midgut epithelial cells from } \\
\text { pathogens }\end{array}$ & Liu et al., 2014 \\
\hline 26 & Cecropins & Musca domestica & Involved in fat body and hemocytes & Xu et al., 2007 \\
\hline 27 & $\begin{array}{l}\text { Glossina morsitans morsitans } \\
\text { yolk protein } 1 \text { (GmmYP1) }\end{array}$ & Glossinidae (tsetse fly) & Major protein found in tsetse "milk" secretions & Attardo et al., 2006 \\
\hline 28 & $\begin{array}{l}\text { Basic-helix-loop-helix-PAS } \\
\text { protein (bHLH-PAS) }\end{array}$ & Drosophila spineless & $\begin{array}{l}\text { Transcription factor involved in control of antennal and } \\
\text { tarsal development }\end{array}$ & Emmons et al., 1999 \\
\hline 29 & $\begin{array}{l}\text { SAS6 (spindle assembling } \\
\text { abnormal protein 6) }\end{array}$ & Delia antique & $\begin{array}{l}\text { Involved in chromosome separation, folate metabolism } \\
\text { and other physiological processes }\end{array}$ & You-Jin et al., 2014 \\
\hline
\end{tabular}


compounds targeting key insect proteins/enzymes revolutionized the insects control methods. Few insecticides like insect growth regulators (IGRs) (juvenile hormone analogs and chitin synthesis inhibitors) and miscellaneous active ingredients (borates, energy inhibitors, and dehydrating dusts) affects the water balance, oxygen metabolism, insect's molting or maturation process, and other aspects of physiology (Nauen and Bretschneider, 2002). Insecticides which act on insect's central nervous system are called neurotoxins. Various components of the acetylcholine system, GABA-gated chloride, and sodium channel modulators are targeted by neurotoxins. Organophosphates (OPs), neonicotinoids, and spinosyns inhibit the acetylcholinesterae (AchE) by removing the neurotransmitter acetylcholine (Ach) from its receptor in the post-synapse nerve and cause overstimulation of the nerve cell and finally insect death (Nauen and Denholm, 2005; Suiter and Scharf, 2011). Further, GABA-gated chloride channels located in the insect central nervous system and peripheral nerves are important target sites for insecticides. Chlorinated cyclodienes (e.g., Dieldrin, Endosulfan-Phasar, Thiodan) are class of insecticides which act on central nervous system. Fipronil binds and blocks the GABA receptor on the post-synapse nerve cell and prevents the influx of chloride ions and leads to the rapidand uncontrolled nerve firing throughout the insect nervous system (Nauen and Bretschneider, 2002). Pyrethroids and oxadiazines are insecticides which interact with sodium channels, the most important molecular target site in insect nervous system. These insecticides disrupt normal nerve function by regulating the sodium channels resulting tremors and quick death (Wing et al., 1998).

Many compounds known to interfere with insect development, in particular with ecdysis (skin shedding), chitin deposition, and entire process of molting are called IGRs (Hoffmann and Lorenz, 1998). IGRs normally interrupt critical physiological functions associated with normal insect growth, development, and reproduction. The IGRs like diflubenzuron, buprofezin, pyriproxyfen, hydroprene, methoprene, fenoxycarb, benzoylphenyl ureas, fenoxycarb, pyriproxyfen, and cryomazine are important insecticides being used for control of many insects (Beckage, 2000). Another class of IGRs is chitin synthesis inhibitors involved in hampering of biochemical pathway of chitin synthesis. Briefly, several chemical and bio insecticides have been developed targeting few of the proteins or enzymes of insects (Table 3). It is interesting to note that some of these targets have been used in RNAi mediated resistance development also. However, it is important to explore more effective targets in years to come which can be achieved by characterizing the role of insect proteins/enzymes in a genome-wide scale.

\section{RNA Interference: Powerful Tool to Target Key Genes of Insects}

RNA interference is an evolutionarily conserved, homology based gene regulation and defense mechanism found in most, if not all eukaryotic organisms. It operates through noncoding small RNA molecules, which recently gained wide spread attention, as molecular switches in complex gene regulatory networks. Several classes of small RNAs are reported which are processed through different enzymatic machinery (Agarwal and Mangrauthia, 2013). These small RNAs are central molecules of RNAi pathway and perform various functions in cells. Among the small RNAs, small interfering RNAs (siRNAs) are associated with defense against parasites, heterochromatin formation, transposons and transgenes silencing and post transcriptional gene silencing. The siRNAs are produced from double stranded RNA (dsRNA) with the help of RNaseIII enzyme dicer and its homologs. These siRNAs loaded with RISC help in identifying the target RNA through Watson-Crick homology. RISC, a multiprotein complex possess endonucleases such as Argonaute and its homologs to cleave the target RNA. This phenomenon has been utilized to attain resistance in plants against pests by producing dsRNAs homologous to the important pest genes. Numerous studies indicate that target gene silencing by RNAi could lead to either insect death or hampered growth and development. The first success of RNAi in insects was achieved with the model organism, the fruit fly D. melanogaster (Kennerdell and Carthew, 1998; Brown et al., 1999) whose genome sequence was published by Adams et al. (2000).

RNAi has been considered as a potential strategy for insect pest control (Zhang et al., 2013b). In past few years, it has become one of the most exciting discoveries of molecular biology, for its high specificity, accuracy, and hereditability. The technologies based on RNAi pathways have shown its potential in a very limited time and in wide range of field applications. The successful history of RNAi technology in crop protection against viruses inspired to achieve insect control by knock down of key enzymes or proteins of insects. The majority of studies on RNAi for insect control have been engrossed on the insect midgut as it is considered as most effective target for the gene silencing. The success of RNAi technology primarily relies on identification of suitable candidate genes to utilize them as targets. Several enzymes and proteins of insects have been identified and characterized (discussed above) which can be useful targets of RNAi. In plants, RNAi is often achieved by a transgene that produces hairpin RNA (hpRNA) with a dsRNA region (Waterhouse and Helliwell, 2003).

There are two primary conditions that need to be addressed to produce dsRNA expressing transgenic plants targeted against pest genes. First, it is important to ensure that adequate amount of dsRNA triggers is produced in plants and ultimately delivered to the pest body to produce an RNAi effect. Second, silencing of target gene through RNAi must cause insect mortality or any other phenotypic change such as preventing feeding, hampered development and/or reproduction. The first condition can be satisfied atleast in those insects which consume plant organs. Expression of dsRNA in plants can be optimized by selecting the specific promoters and other regulatory elements such as enhancers or suppressors. However, the second condition is not easy and purely depends on selection of target gene which determines the effect of RNAi on insect phenotype. Further, some studies have shown that transgenic plants expressing dsRNAs directed against insect genes showed enhanced resistance suggesting that RNAi was still active insect body. However, it is important to analyze the RNAi effects in case by case, as absence 
TABLE 3 | Mode of action, target site, and primary route of entry of commonly used insecticide classes.

\begin{tabular}{|c|c|c|c|}
\hline Chemical class/group & Active ingredients/examples of trade names & Mode of action & Targeted site/process \\
\hline \multicolumn{4}{|c|}{ INSECTICIDES THAT TARGET THE INSECT NERVOUS SYSTEM } \\
\hline Carbamates & $\begin{array}{l}\text { Aldicarb (Temik), Bendiocarb (Garvox), Carbofuran (Furadan), Carbosulfan } \\
\text { (Advantage), Promecarb (Carbamult), Methiocarb (Mesurol) }\end{array}$ & $\begin{array}{l}\text { Acetyl cholinesterase } \\
\text { inhibitor }\end{array}$ & Nerve synapse \\
\hline Organo Phasphates & $\begin{array}{l}\text { Acephate (Orthene), Chlorpyrifos (Lorsban), Disulfoton (Di-Syston), Fenthion } \\
\text { (Baycid), Monocrotophos (Azodrin), Phorate (Thimet) }\end{array}$ & $\begin{array}{l}\text { Acetyl cholinesterase } \\
\text { inhibitor }\end{array}$ & Nerve synapse \\
\hline Pyrethrins/Pyrethoids & $\begin{array}{l}\text { Bifenthrin (Brigade), Cypermethrin (Ripcord), Fluvalinate (Mavrik), Permethrin } \\
\text { (Talcord) }\end{array}$ & Sodium channel modulators & Axon of nerve \\
\hline Neonicotinoids & $\begin{array}{l}\text { Acetamiprid (pristine), Clothiamidin (poncho), Imidacloprid (Advantage), } \\
\text { Thiacloprid (calypso) }\end{array}$ & $\begin{array}{l}\text { Acetylcholine receptor } \\
\text { agonist (mimic) }\end{array}$ & Nerve post-synapse \\
\hline Avermectins & $\begin{array}{l}\text { Abamectin B1 (Advert, Agri-Mek, Vertimec), Emamectin benzoate (Denim, } \\
\text { Proclaim) }\end{array}$ & Chloride channel activators & Nerve post-synapse \\
\hline Oxadiazins & Indoxacarb (Avaunt, Steward) & $\begin{array}{l}\text { Voltage-dependent sodium } \\
\text { channel blocker }\end{array}$ & Axon of nerve \\
\hline Spinosys & Spinosad (Entrust, NaturaLyte, SpinTor, Success, Tracer) & $\begin{array}{l}\text { Nicotinic acetylcholine } \\
\text { receptor agonists (allosteric) }\end{array}$ & Nerve post-synapse \\
\hline Phenylpyrazoles & Fipronil (Regent) & $\begin{array}{l}\text { GABA-gated chloride } \\
\text { channel antagonists }\end{array}$ & Nerve post-synapse \\
\hline \multicolumn{4}{|c|}{ INSECTICIDES THAT DO NOT TARGET THE INSECT NERVOUS SYSTEM } \\
\hline Juvenile hormone analogs & $\begin{array}{l}\text { Fenoxycarb (Comply) } \\
\text { Hydroprene (GenTrol) } \\
\text { Methoprene (Apex) } \\
\text { Pyriproxyfen (Archer, Knack) }\end{array}$ & $\begin{array}{l}\text { Mimic juvenile hormone } \\
\text { action }\end{array}$ & Growth and development \\
\hline Chitin synthesis inhibitors & buprofezin (Applaud), cyromazine (Trigard) & Chitin synthesis inhibitor & Exoskeleton \\
\hline Pyrroles & Chlorfenapyr (Alert, Pirate, Pylon) & $\begin{array}{l}\text { Oxidative phosphorylation } \\
\text { disruption-uncoupler }\end{array}$ & $\begin{array}{l}\text { Metabolic processes/Energy } \\
\text { production }\end{array}$ \\
\hline Fumigant (sulfuryl fluoride) & Sulfuryl fluoride (Vikane) & $\begin{array}{l}\text { Disruption of the glycolysis } \\
\text { and fatty acid cycles }\end{array}$ & $\begin{array}{l}\text { Metabolic processes/energy } \\
\text { production }\end{array}$ \\
\hline Borates & $\begin{array}{l}\text { Borax(Boracide) } \\
\text { Boric acid(Bonide Roach Powder, Enforcer Roach Ridd) }\end{array}$ & $\begin{array}{l}\text { Miscellaneous non-specific } \\
\text { (multi-site) inhibitors }\end{array}$ & Cells \\
\hline
\end{tabular}

Table is derived from data developed and organized by the Insecticide Resistance Action Committee IRAC (2014), http://www.irac-online.org/modes-of-action/, and Brown and Ingianni, 2013.

of RNAi machinery has been reported in few insects and other organisms. Further, in some cases, though RNAi machinery is present, but it does not show systemic effects (Gatehouse and Price, 2011).

RNAi has advantage over the existing technologies of insect control as it can target either specific insect or group of insects depending on the dsRNA trigger sequence. If RNAi has to be produced against specific insect, a unique and specific gene sequence should be selected for dsRNA production. In order to produce RNAi transgenic plants for multiple insect resistances, gene sequence conserved in those insects need to be identified for targeting through RNAi. Thus, selection of gene sequence for dsRNA production determines the spectrum of resistance in transgenic plants. Further, multiple insect resistance plants can also be obtained by pyramiding of gene constructs either at the time of transformation or through breeding approach.

Though RNAi is a conserved phenomenon, it shows difference in mode of action in different insect orders. Three genes, sid-1, -2 , and -3 , were identified in C.elegans which are necessary for systemic RNAi effects in nematodes (Winston et al., 2002). The encoded protein of sid-1 was characterized as a transmembrane protein that functions as a pore or channel that transports dsRNA or siRNA into and out of cells. SID1 or its homolog has not been identified in D. melanogaster which does not show systemic RNAi effects. Further, systemic nature of RNAi is also determined by presence of absence of an enzyme RNA dependent RNA polymerase (RdRP) which helps in amplifying the silencing signal. The characteristic domains of RdRP have not been identified in insects genome, however, Tribolium confusum, a red flour beetle shows a strong, systemic, and transgenerational RNAi response. Interestingly, Tribolium shows RNA amplification through a mechanism possibly distinct from that observed in C. elegans. A genome-wide analysis suggested that several components of the RNAi are different between C. elegans and T. confusum (Tomoyasu et al., 2008). Initially, the SID1 was thought to be the determining factor of systemic nature of RNAi in insects given the fact that three homologs of sid-1 were identified in T. confusum (showing systemic RNAi), while it was absent in Drosophila (non-systemic RNAi). Later, with the help of other insect genomes, it was proposed that the presence of sid-1 homologs and systemic RNAi responses does not have direct correlation, suggesting that transport of dsRNA into and out of cells differ between insects and nematodes, and probably between the insect orders (Tomoyasu et al., 2008). Beside 
the Tribolium, other insects e.g., the wasp Nasonia vitripennis also have shown the transfer of dsRNA from one generation to another, suggesting the presence of systemic RNAi (Lynch and Desplan, 2006). Silencing of genes expression through RNAi has been demonstrated in several insect orders such as Diptera, Lepidoptera, Coleoptera, Orthopetra, Hymenoptera, Blattodea, and Hemiptera (Misquitta and Paterson, 1999; Bucher et al., 2002; Rajagopal et al., 2002; Amdam et al., 2003; Dong and Friedrich, 2005; Cruz et al., 2006; Mutti et al., 2006). However, the efficiency of the RNAi based genes suppression is variable in different insect species due to presence/absence of systemic RNAi and several other silencing components. Infact, transgenic plants producing dsRNAs directed against genes function in Lepidoptera, Coleoptera, and Hemiptera pests have shown encouraging results which need to be translated as commercial products against several other important crop insects (Baum et al., 2007; Gordon and Waterhouse, 2007; Mao et al., 2007; Chen et al., 2010; Agarwal et al., 2012). The biochemical machinery and steps involved in RNAi based insect resistance are described in Figure 1.

\section{Proven RNAi-Based Approaches of Insect Resistance}

Hydroxy-3-methylglutaryl coenzyme A reductase (HMG-CoA reductase; HMGR) is a key enzyme in the mevalonate pathway of insects which is a potential RNAi target in case of Helicoverpa armigera. Silencing of HMGR using systemic RNAi inhibited the fecundity of the females, ovipostion, and significantly reduced vitellogenin (Vg) mRNA levels (Wang et al., 2013). RNA interference mediated down-regulation of cathepsin D of the silkworm Bombyx mori (BmCatD) resulted in the arrest of larval-pupal transformation (Gui et al., 2006). Knockdown of polygalacturonase (PG) gene in L. lineolaris bugs through injection with PG1 dsRNA reduced the expression of PG1 (Walker and Allen, 2010). RNAi based silencing of aminopeptidase- $N$ (APN) and cadherin of $H$. armigera showed reduction of $H a A P N 1$ transcript levels after dsRNA incubation. This treatment also resulted in a corresponding decrease in the protein expression levels (Sivakumar et al., 2007). In another study, Rajam and coworkers silenced the acetylcholinesterase gene of $H$. armigera by feeding siRNAs which hampered larval growth (Kumar et al., 2009). Bautista et al., 2009 studied the influence of silencing the cytochrome P450 gene CYP6BG1 in permethrin resistance in diamondback moth (Plutella xylostella) through oral delivery of dsRNAs. In another report, cytochrome P450 6 B46 (CYP6B46) -silenced larvae of Manduca sexta showed impaired mechanisms of passing ingested nicotine from the midgut to the hemolymph, thus making them susceptible to predators(Kumar et al., 2014). In yet another report, the cotton bollworm larvae were fed on RNAi transgenic leaves, showing reduced levels of cytochrome P450 (CYP6AE14) mRNA and retarded larval growth (Mao et al., 2007). NADPH-cytochrome P450 reductase (CPR) plays a central role in cytochrome $\mathrm{P} 450$ action of Cimex lectularius. The injection of dsRNA of $C l C P R$ gene successfully suppressed the gene expression in all body parts indicating that the RNAi effect in bed bugs is systemic (Zhu et al., 2012). In a very short span of time, several efforts have been made to develop insect resistance using RNAi based targeting of key insect genes (Table 4).

\section{Challenges of RNAi Based Insect Resistance}

Several fine tuning steps need to be taken up before the success of insect control through RNAi can be fully realized. More intensive research is needed to identify improved siRNA delivery methods, prediction of effective target genes and siRNAs, identifying the conserved gene sequences, stability and durability of gene silencing effects. Further, important factors determining the success of RNAi in insect control would be identifying the RNAi machinery in important insect species, identifying novel and effective gene targets of RNAi, identifying the correct life stage of insect to be targeted, identifying the right tissue of plants for siRNA biogenesis and optimization of required concentration of siRNAs to kill insect, nullifying the off target effects of siRNAs in useful and non-targeted organisms, and biosafety assays of RNAi products.

More gene orthologs involved in key metabolic pathways of insects should be identified and their roles need to be characterized. Use of advanced genomics and proteomics tools will hasten the process of identification of crucial genes/ proteins. Generally, the candidate targets of RNAi may be any gene showing detrimental lethal phenotype on insect life cycle. The genome sequence information of insects has currently around 340,000 of total sequences for beetles (http://www.ncbi.nlm.nih.gov/ nuccore/). Only eight coleopteran species have more than 5000 sequences deposited- Pogonus chalceus (65779), Dendroctonus ponderosae (41429), Rhynchophorus ferrugineus (27014), Dendroctonus frontalis (20987), T. castaneum (16808), Ips typographus (14810), Agrilus planipennis (12018), and A. grandis (5705), (Firmino et al., 2013; i5K Consortium, 2013). More sequences from diverse insect species will help in identifying useful gene targets of RNAi. Development of insect cell lines especially from midgut microvillar epithelial cells will facilitate in deciphering the dsRNA uptake mechanism. It will help in developing effective siRNA delivery methods. Development of non-reactive material for coating of siRNAs will further enhance the scope of delivery. Target siRNAs can be delivered through nano particles coated with dsRNA to enhance its uptake by the gut and in turn the efficiency of the silencing. To make it more stable and heritable insect control tool, siRNA producing gene constructs can be developed which can become resources to produce novel insect resistant transgenic crops. Here, siRNA production can be optimized by using either tissue or stage specific promoters, and enhancers. Despite significant progress in understanding the siRNA uptake mechanism, there is a need to develop effective artificial diets for some important insects like yellow stem borer of rice. It will augment the testing and validation of the RNAi targets. Further, tagging the siRNA with florescent dyes will help to track the siRNAs movement in the insect body.

Although RNAi is conserved pathway among several eukaryotes but it has diversified a lot in the course of evolution 


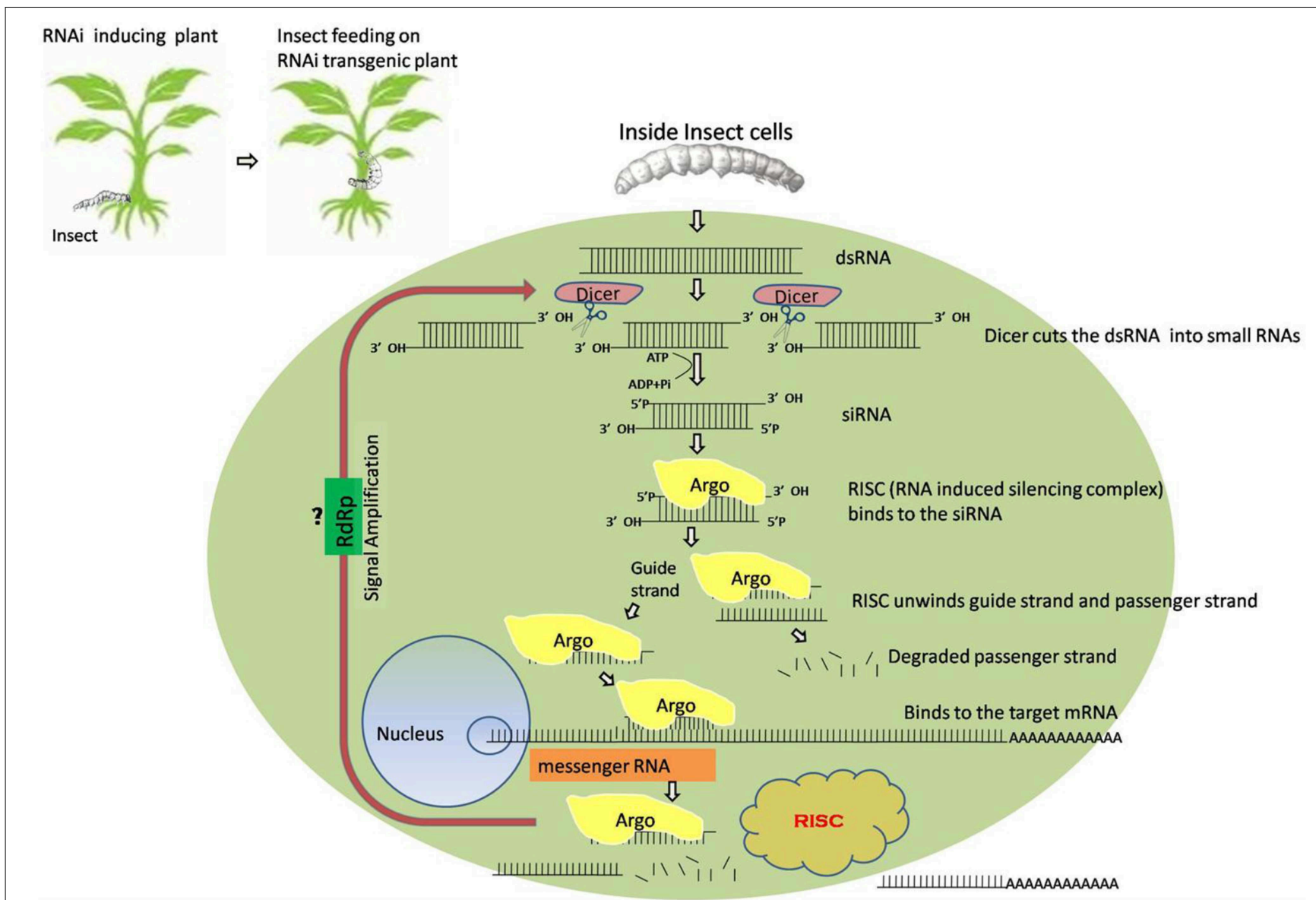

Cleaves the target site and no more protein is synthesized. Larval growth and metabolism consequently arrest

FIGURE 1 | Systematic illustration of gene silencing by RNAi inside the insect cells. Double stranded RNA (dsRNA) of target genes are formed, which trigger RNAi machinery. dsRNAs are processed by RNAse III enzyme Dicer to synthesize 21 nucleotide small interfering RNAs (siRNAs). RNAi inducing silencing complex (RISC) binds these siRNAs. The guide strand of
siRNAs helps RISC to target the corresponding mRNA. Argonaute protein (Argo) present in RISC complex cleaves the target mRNA. The cleaved target mRNA is amplified by RNA dependent RNA polymerase (RdRp) to form dsRNAs, which enter in RNAi pathway and amplify the signal. However, the signal amplification step in insects is not yet very well understood.
(Shabalina and Koonin, 2008). Infact, in some organisms such as Saccharomyce cerevisiae, and Ustilago maydis, the entire RNA silencing machinery appears to be lost (Nakayashiki and Nguyen, 2008). Therefore, it is necessary to probe more into the elements of RNAi machinery in different insects species before applying RNAi in a given insect.

\section{Delivery Methods of RNAi}

RNAi shows its impact once the dsRNA is delivered into the cell (Yu et al., 2013). The dsRNA delivery methods used till today are oral feeding, microinjection, RNAi transgenic crops, soaking and transfection methods (Huvenne and Smagghe, 2010). The oral delivery of dsRNA in insects is one of the efficient approaches of RNAi. It was first demonstrated in C. elegans, (Timmons and Fire, 1998). Recently, it was shown in H.armigera with siRNAs designed from AChE (Kumar et al., 2009). Though it is simple method of dsRNA delivery, it has many disadvantages like heritability and stability issues, and many of the insects do not have the diet to complete its life cycle. Microinjection is another most commonly used method for dsRNA delivery in insects (Arakane et al., 2005; Suzuki et al., 2008). Though it is a precise way of dsRNA delivery, it requires technical expertise and specific equipments, so it is not much popular in many insect systems.

In recent years, soaking the organism into a dsRNA solution seems to be a popular method for triggering RNAi response mainly because of its convenient operation (Yu et al., 2013). The first experiment regarding soaking was reported by Tabara group in which they found that specific RNAi was induced by simply soaking of $C$. elegans in the dsRNA solution (Tabara et al., 1998). Thus, this technique was applied for large-scale analysis of gene function in this species to accomplish high-throughput RNAi (Maeda et al., 2001). The dsRNA delivery methods such as oral feeding, microinjection, soaking, and transfection are important in studying RNAi in insects, however, these methods do not seem to be of great help as concerns the defense of plants against insects. 
TABLE 4 | List of genes encoding key enzymes/proteins used in RNAi mediated insect resistance.

\begin{tabular}{|c|c|c|c|c|c|c|}
\hline S.No & Target gene & $\begin{array}{l}\text { Type of RNAi } \\
\text { construct }\end{array}$ & Crop/plant & Delivery method & Reported insects & References \\
\hline 1. & Adenylatekinase 2 (AK2) & dsRNA & - & Feeding & Helicoverpa, Drosophila & Chen et al., 2012 \\
\hline 2. & Vacuolar-ATPase A V-ATPase E & dsRNA & - & Ingestion and injection & $\begin{array}{l}\text { Peregrinus maidis, and } \\
\text { Bemisia tabaci Diabrotica } \\
\text { virgifera virgifera }\end{array}$ & $\begin{array}{l}\text { Baum et al., 2007; } \\
\text { Upadhyay et al., 2011; Yao } \\
\text { et al., } 2013\end{array}$ \\
\hline 3. & $\alpha$-Tubulin & dsRNA & - & Feeding & D.virgifera virgifera & Baum et al., 2007 \\
\hline 4. & Carboxylesterases (CarEs) & dsRNA & - & Injection & Locusta migratoria & Zhang et al., 2014 \\
\hline 5. & $\begin{array}{l}\text { Carboxylesterase gene EposCXE1 } \\
\text { and pheromone binding protein gene } \\
\text { EposPBP1 }\end{array}$ & dsRNA & - & Oral delivery /feeding & Epiphyas Postvittana & Turner et al., 2006 \\
\hline 6. & Catalase (CAT) & dsRNA & - & Injection & Spodoptera litura & Zhao et al., 2013 \\
\hline 7. & Superoxide dismutase & dsRNA & - & Injection & Culex pipiens & Sim and Denlinger, 2011 \\
\hline 8. & Laccase 2 (Lac2) & dsRNA & - & Injection & D.virgifera virgifera & Alves et al., 2010 \\
\hline 9. & Arginine kinase & dsRNA & - & Feeding & Phyllotreta striolata & Zhao et al., 2008 \\
\hline 10. & Allatotropin & dsRNA & - & Injection & Tribolium castaneum & $\begin{array}{l}\text { Abdel-latief and Hoffmann, } \\
2014\end{array}$ \\
\hline 11. & Allatostatin C & dsRNA & - & Injection & T. castaneum & $\begin{array}{l}\text { Abdel-latief and Hoffmann, } \\
\text { 2014; Lungchukiet et al., } \\
2008\end{array}$ \\
\hline 12. & Trehalose phosphate synthase (TPS) & dsRNA & - & Feeding & Nilaparvata Lugens & Chen et al., 2010 \\
\hline 13. & Vitellogenin protein & dsRNA & - & Injection & S.litura & Shu et al., 2011 \\
\hline 14. & Cytochrome P 450 CYP6BG1 & dsRNA & - & Feeding & Plutella xylostella & Bautista et al., 2009 \\
\hline 15 & CYP6B6 & dsRNA & - & Feeding & H. armigera & Zhang et al., 2013a \\
\hline 16 & CYP6AE14 & $\begin{array}{l}\text { pBI121- } \\
\text { pCAM- } \\
\text { BIA1300 }\end{array}$ & $\begin{array}{l}\text { Arabidopsis } \\
\text { and } \\
\text { Tobacco }\end{array}$ & Feeding & H.armigera & Mao et al., 2007 \\
\hline 17 & Aminopeptidase N & dsRNA & - & Injection & S.litura & Rajagopal et al., 2002 \\
\hline 18 & $\begin{array}{l}\text { 3-hydroxy-3-methylglutaryl coenzyme } \\
\text { A reductase (HMG-CoA reductase; } \\
\text { HMGR) gene }\end{array}$ & dsRNA & - & Injection & H. armigera & Wang et al., 2013 \\
\hline 19 & Tryptophan oxygenase & dsRNA & - & Injection & Plodia interpunctella & Lorenzen et al., 2002 \\
\hline 20 & HaHR3 & $\begin{array}{l}\text { pCAMBIA2300- } \\
\text { 35s-OCS }\end{array}$ & Tobacco & $\begin{array}{l}\text { Feeding bioassays and } \\
\text { transgenic expressing } \\
\text { hairpin RNAs }\end{array}$ & H.armigera & Xiong et al., 2013 \\
\hline 21 & Hexose transporter gene NIHT1 & $\mathrm{pCU}$ & Rice & Hairpin RNAi construct. & N.lugens & Zha et al., 2011 \\
\hline 22 & Carboxypeptidase gene Nlcar & $\mathrm{pCU}$ & Rice & Hairpin RNAi construct. & N.lugens & Zha et al., 2011 \\
\hline 23 & Circadian clock gene per & dsRNA & - & Injection & Gryllus Bimaculatus & Moriyama et al., 2008 \\
\hline 24 & Salivary nitrophorin 2 gene NP2 & dsRNA & - & Injection & Rhodnius prolixus & Araujo et al., 2006 \\
\hline 25 & Eye color gene vermilion & dsRNA & - & Injection & Schistocerca Americana & Dong and Friedrich, 2005 \\
\hline 26 & Trypsin-like serine protease gene N/try & $\begin{array}{l}\text { Hairpin RNAi } \\
\text { construct }\end{array}$ & Rice & . & N.lugens & Zha et al., 2011 \\
\hline 27 & Circadian clock gene & dsRNA & - & Injection & S. littoralis & Kotwica et al., 2009 \\
\hline 28 & $\beta$-actin gene & dsRNA & - & Injection & S. littoralis & Gvakharia et al., 2003 \\
\hline 29 & Glutathione-S-transferase gene GST1 & dsRNA & - & Feeding & H. armigera & Mao et al., 2007 \\
\hline 30 & Chitin synthase gene & dsRNA & - & Injection & S. exigua & Chen et al., 2008 \\
\hline 31 & $\begin{array}{l}\text { Chitin synthase genes TcCHS1 and } \\
\text { TcCHS2 }\end{array}$ & dsRNA & - & Injection & T. castaneum & Arakane et al., 2005 \\
\hline 32 & $\begin{array}{l}\text { Chitinase like proteins TcCHT5, } \\
\text { TcCHT10, TcCHT7, and TcIDGF4 }\end{array}$ & dsRNA & - & Injection & T. castaneum & Zhu et al., 2008 \\
\hline 33 & Polygalacturonase & dsRNA & - & Injection & Lygus lineolaris & Walker and Allen, 2010 \\
\hline 34 & Acetylcholinesterase & dsRNA & - & Feeding & H. armigera & Kumar et al., 2009 \\
\hline
\end{tabular}


RNAi trigger can also be delivered in insects through transgenic plants. In a recent study, pCAMBIA-RNAi-HaHR3 construct was developed and transformed into tobacco (Nicotiana tabacum) expressing the HaHR3 mRNA hairpin which resulted developmental deformity and larval lethality of $H$. armigera (Xiong et al., 2013). Tobacco and Arabidopsis transgenics expressing CYP6AE14 -siRNAs of the $H$. armigera inhibited expression of the CYP6AE14 mRNA in this lepidopteron pest. The suppression of CYP6AE14 expression in these insects caused increased sensitivity to the natural defense compound, gossypol, produced by the cotton plant (Mao et al., 2007). In another study, transgenic corn plants expressing V-ATPase-dsRNA of the western corn rootworm showed resistance to feeding damage by this lepidopteron pest (Baum et al., 2007). Transgenic rice developed based on RNAi of three separate genes expressed in the midgut of the brown plant hopper, Nilaparvata lugens Stål showed a reduced expression of target genes in this insect (Zha et al., 2011). Further, transgenic Arabidopsis targeting receptor of activated kinase (Rack-1) gene was developed to induce RNAi in the gut of the aphid Myzus persicae (Pitino et al., 2011). In yet another study, transgenic tobacco expressing dsRNA of v-ATPaseA gene showed enhanced resistance against whitefly (Thakur et al., 2014). The persistence and trans-generational effects of plant-mediated RNAi based on Rack1, MpC002, and $\mathrm{MpPIntO} 2$ genes was reported in the green peach aphid (GPA) M. persicae using transgenic Arabidopsis (Coleman et al., 2015). Overall, delivery of dsRNAs through transgenic approach has been successful in some cases while it was discouraging in other reports. Of course, it has advantage over other methods of delivery in terms of stability, heritability and optimization of dsRNA expression in specific tissues and quantity. However, this method of dsRNA delivery relies on feeding behavior of insects on transgenic crops. Therefore, it is necessary to examine and identify appropriate dsRNA or siRNA delivery methods in a case wise manner.

\section{Off-Targeting}

Although, initially gene silencing by RNAi was believed to be specific, recent reports have shown that off-targeting can widely occur during RNAi (Xu et al., 2006). It was reported in Triatomid bug (R. prolixus) while silencing nitroporin 2 (Araujo et al., 2006). Though, siRNA sequences are highly specific to the target genes, non-specific hybridization of siRNAs with non-target transcripts can induce unintended effects (Jackson et al., 2003). Therefore, it is important to ensure that the dsRNA and corresponding siRNA sequences do not exert off-target effects that negatively impact host plant physiology, potential non target host colonizers and/or mammals that feed on the modified crop (Koch and Kogel, 2014).

Sequence similarity between siRNA and target gene, mRNA sequence selected for RNAi, size of siRNA, and transitive RNAi determine off-target silencing. Use of highly specific sequences in siRNA and controlling their expression through specific and inducible promoters can minimize off targeting effects. Further, off targeting effects can be minimized using artificial microRNA technology that provides a way to design specific siRNAs instead of using additional sequences (Schwab et al., 2006; Warthmann et al., 2008; Ai et al., 2011). While selecting the targets, it is important to select the genes which are unique and do not occur as gene family or homologous genes. Also, silencing of genes associated with regulatory functions and multiple metabolic pathways such as transcription factors or signaling molecules may lead to unintended effects on host. Therefore, it is important to examine the off target effects of RNAi at multiple levels. First, designing of siRNA to silence a particular gene in any organism must ensure that it does not target any other mRNA of its own. Second, off targeting of siRNA need to be checked in other closely associated plants/crops which can be cross pollinated. Third, possible off targeting impacts need to be analyzed on microorganisms and insects cohabiting with RNAi plants. Particularly, it needs to be assessed for useful and non-targeted organisms. In order to make sure that other non-harmful insects are not killed, selection of target genes through screening would be appropriate approach. Genes playing essential functions and unique to target insects need to be selected. House-keeping genes including those encoding various ribosomal proteins, and components of conserved systems such as proteasomes and transport or genes belonging to conserved multi-gene family may affect non-harmful insects. The insect genes whose products are necessary for detoxification of a secondary metabolite in the plant host may be appropriate. Here, developing a genome wide sequence and transcriptome databases of non-harmful insects for different ecologies will facilitate in selection of genes which will not affect non-target organisms. Fourth, off targeting also need be analyzed on animals grazing on such plants/crops. Most importantly, if RNAi is introduced in food crops, off targeting of siRNAs need to be checked against human genome. In order to achieve this, genome sequence data, transcriptome data, or EST databases of plants, animals, and microorganisms will be extremely important to search homologous off target sequences. However, the gene/genome sequences of most of the predator parasites are not available. Though, appreciable increase in genome and transcriptome databases has been witnessed after the commencement of next generation sequencing tools and advanced bioinformatics pipelines. Currently, the prediction of off targeting is done through bioinformatics approaches using the existing gene sequence databases (Agarwal and Mangrauthia, 2013). Therefore, it will be important to develop databases of different organisms which can be utilized to predict the possible off target effects. One such database has been developed called siRNA Scan (http://bioinfo2.noble.org/RNAiScan.htm) to identify potential off-targets in plants (Senthil-Kumar and Mysore, 2011).

\section{Future Prospects}

Tremendous progress has been achieved in using RNAi technology to understand gene regulation and function in humans and other animal systems. RNA interference has become an indispensable tool for loss-of-function studies across eukaryotes (Fellmann and Lowe, 2014). Applications of RNAi are extended to plant system for functional genomics. Advancement of this technology is also evident in developing resistance against viruses and fungi in some crop plants (Wani et al., 2010; Duan et al., 2012). However, use of this technology for insect control is in 
beginning and the progress is encouraging. Undoubtedly, it has several merits over the existing methods of insect control. To make this technology more viable and effective, intensive studies are required to understand the insect biology. High throughput genomics and proteomics tools need to be utilized effectively for detecting real candidate genes encoding key proteins or enzymes which are still not characterized in systems approach. Classical studies are required to develop the artificial diets and more effective siRNA delivery methods. Funding is required to generate sequence databases of beneficial and harmless insects and insect predators of important crop ecologies. International consortia to develop such sequence database can be formed. Though suppressors of RNAi pathway have been well documented in the virus system (Praveen and Mangrauthia, 2006; Mangrauthia et al., 2010), the research efforts are needed to see if such suppressors are existing in the insects also to counter the RNAi based plant defense. Though RNAi technology seems to be safer

\section{References}

Abdel-latief, M. A., and Hoffmann, K. H. (2014). Functional activity of allatotropin and allatostatin in the pupal stage of a holometablous insect, Tribolium castaneum (Coleoptera, Tenebrionidae). Peptides 53, 172-184. doi: 10.1016/j.peptides.2013.10.007

Adams, M. D., Celniker, S. E., Holt, R. A., Evans, C. A., Gocayne, J. D., Amanatides, P. G., et al. (2000). The genome sequence of Drosophila melanogaster. Science 287, 2185-2195. doi: 10.1126/science.287.5461.2185

Agarwal, S., and Mangrauthia, S. K. (2013). Advances, challenges and prospects in small RNA mediated approaches of virus resistance in plants. J. Genomes Exomes 2, 43-62. doi: 10.4137/JGE.S11938

Agarwal, S., Mohan, M., and Mangrauthia, S. K. (2012). "RNAi: machinery and role in pest and disease management," in Crop Stress and its Management: Perspectives and Strategies, eds B. Venkateshwarlu, A. K. Shankar, C. Shankar, and M. Maheshwari (Springer), 447-469.

Ai, T., Zhang, L., Gao, Z., Zhu, C. X., and Guo, X. (2011). Highly efficient virus resistance mediated by artificial microRNAs that target the suppressor of PVX and PVY in plants. Plant Biol. (Stuttg). 13, 304-316. doi: 10.1111/j.14388677.2010.00374.x

Alves, A. P., Lorenzen, M. D., Beeman, R. W., Foster, J. E., and Siegfried, B. D. (2010). RNA interference as a method for target-site screening in the Western corn rootworm, Diabrotica virgifera virgifera. J. Insect Sci. 10, 1-16. doi: 10.1673/031.010.14122

Amdam, G. V., Simoes, Z. L., Guidugli, K. R., Norberg, K., and Omholt, S. W. (2003). Disruption of vitellogenin gene function in adult honeybees by intra-abdominal injection of double-stranded RNA. BMC Biotechnol. 3:1. doi: 10.1186/1472-6750-3-1

Arakane, Y., and Muthukrishnan, S. (2010). Insect chitinase and chitinaselike proteins. Cell. Mol. Life Sci. 67, 201-216. doi: 10.1007/s00018-0090161-9

Arakane, Y., Muthukrishnan, S., Kramer, K. J., Specht, C. A., Tomoyasu, Y., Lorenzen, M. D., et al. (2005). The Tribolium chitin synthase genes TcCHS1 and TcCHS2 are specialized for synthesis of epidermal cuticle and midgut peritrophic matrix. Insect Mol. Biol. 14, 453-463. doi: 10.1111/j.13652583.2005.00576.x

Araujo, R. N., Santos, A., Pinto, F. S., Gontijo, N. F., Lehane, M. J., and Pereira, M. H. (2006). RNA interference of the salivary gland nitrophorin 2 in the triatomine bug Rhodnius prolixus (Hemiptera: Reduviidae) by dsRNA ingestion or injection. Insect Biochem. Mol. Biol. 36, 683-693. doi: 10.1016/j.ibmb.2006.05.012

Ashida, M., Reiko, I., and Yoshida, H. (1982). "Control and function of the prophenoloxidase activating system," in Proceedings 3rd International Colloquium (Brighton: Invertebrate pathonogy, University of Sussex), 81-86. than protein based transgenic technology, still more studies on biosafety issues are required to popularize the technology which will help in bringing safer products into the environment and commercial markets. Importantly, RNAi needs to be designed to limit inter-species activity by selecting the appropriate genes and dsRNA trigger sequences. Here, genome, transcriptome and EST databases will play crucial role in identifying specific targets of RNAi. In particular, the dsRNA trigger sequences need to be cross checked with human genome and transcriptome considering that many of the putative insect targets may also be important in human (patho) physiology.

\section{Acknowledgments}

Authors are highly thankful to the Project Director, DRR for help and support. The financial assistance received from DBT, government of India is acknowledged.

Attardo, G. M., Guz, N., Strickler-Dinglasan, P., and Aksoy, S. (2006). Molecular aspects of viviparous reproductive biology of the tsetse fly (Glossina morsitans morsitans): regulation of yolk and milk gland protein synthesis. J. Insect Physiol. 52, 1128-1136. doi: 10.1016/j.jinsphys.2006.07.007

Ayme-Southgate, A. J., Turner, L., and Southgate, R. J. (2013). Molecular analysis of the muscle protein projectin in Lepidoptera. J. Insect Sci. 13. 88-102. doi: 10.1673/031.013.8801

Balczun, C., Siemanowski, J., Pausch, J. K., Helling, S., Marcus, K., Stephan, C., et al. (2012). Intestinal aspartate proteases TiCatD and TiCatD2 of the haematophagous bug Triatoma infestans Reduviidae): sequence characterisation, expression pattern and characterisation of proteolytic activity. Insect Biochem. Mol. Biol. 42, 240-250. doi: 10.1016/j.ibmb.2011.12.006

Baum, J. A., Bogaert, T., Clinton, W., Heck, G. R., Feldmann, P., Ilagan, O., et al. (2007). Control of coleopteran insect pests through RNA interference. Nat. Biotechnol. 25, 1322-1326. doi: 10.1038/nbt1359

Bautista, M. A., Miyata, T., Miura, K., and Tanaka, T. (2009). RNA interferencemediated knockdown of a cytochrome P450, CYP6BG1, from the diamondback moth, Plutella xylostella, reduces larval resistance to permethrin. Insect Biochem. Mol. Biol. 39, 38-46. doi: 10.1016/j.ibmb.2008.09.005

Beckage, N. E. (2000). "Insect growth regulators," in Biological and Biotechnological Control of Insect Pests, eds J. E. Rechcigl and N. A. Rechcigl (Boca Raton, FL; NewYork, NY; Washington, DC: Lewis Publishers), 123-137.

Beverley, S. M., and Wilson, A. C. (1982). Molecular evolution in Drosophila and higher dipteral. J. Mol. Evol. 18, 251-264. doi: 10.1007/BF01734103

Bown, D. P., and Gatehouse, J. A. (2004). Characterization of a digestive carboxypeptidase from the insect pest corn earworm (Helicoverpa armigera) with novel specificity towards C-terminal glutamate residues. Eur. J. Biochem. 271, 2000-2011. doi: 10.1111/j.1432-1033.2004.04113.x

Bragatto, I., Genta, F. A., Ribeiro, A. F., Terra, W. R., and Ferreira, C. (2010). Characterization of a $\beta$-1, 3-glucanase active in the alkaline midgut of Spodoptera frugiperda larvae and its relation to $\beta$-glucan-binding proteins. Insect Biochem. Mol. Biol. 40, 861-872. doi: 10.1016/j.ibmb.2010.08.006

Brennan, Y., Callen, W. N., Christoffersen, L., Dupree, P., Goubet, F., Healey, S., et al. (2004). Unusual microbial xylanases from insect guts. Appl. Environ. Microbiol. 70, 3609-3617. doi: 10.1128/AEM.70.6.3609-3617.2004

Brown, A. E., and Ingianni, E. (2013). Mode of Action of Insecticides and Related Pest Control Chemicals for Production Agriculture, Ornamentals, and Turf, Pesticide information Leaf let. University of Maryland Pesticide Education and Assessment Programs. 1-13. Available online at: http://pesticide/umd.edu.

Brown, S. J., Mahaffey, J. P., Lorenzen, M. D., Denell, R. E., and Mahaffey, J. W. (1999). Using RNAi to investigate orthologous homeotic gene function during development of distantly related insects. Evol. Dev. 1, 11-15. doi: 10.1046/j.1525-142x.1999.99013.x 
Bucher, G., Scholten, J., and Klingler, M. (2002). Parental RNAi in Tribolium (Coleoptera). Curr. Biol. 12, R85-R86. doi: 10.1016/S0960-9822(02) 00666-8

Chapman, R. F. (1998). The Insects: Structure and Function, 4th Edn. Cambridge: Cambridge University Press.

Chen, J., Zhang, D., Yao, Q., Zhang, J., Dong, X., Tian, H., et al. (2010). Feeding-based RNA interference of a trehalose phosphate synthase gene in the brown planthopper, Nilaparvata lugens. Insect Mol. Biol. 19, 777-786. doi: 10.1111/j.1365-2583.2010.01038.x

Chen, R. P., Liu, C. Y., Shao, H. L., Zheng, W. W., Wang, J. X., and Zhao, X. F. (2012). Adenylate kinase 2 (AK2) promotes cell proliferation in insect development. BMC Mol. Biol. 13:31. doi: 10.1186/14712199-13-31

Chen, X., Lu, S., and Zhang, Y. (2014). Characterization of protein phosphatase 5 from three Lepidopteran insects: Helicoverpa armigera, Mythimna separata and Plutella xylostella. PLoS ONE 9:e97437. doi: 10.1371/journal.pone. 0097437

Chen, X., Tian, H., Zou, L., Tang, B., Hu, J., and Zhang, W. (2008). Disruption of Spodoptera exigua larval development by silencing chitin synthase gene A with RNA interference. Bull. Entomol. Res. 98, 613-619. doi: 10.1017/S0007485308005932

Chirila, T. V., Suzuki, S., Bray, L. J., Barnett, N. L., and Harkin, D. G. (2013). Evaluation of silk sericin as a biomaterial: in vitro growth of human corneal limbal epithelial cells on Bombyx mori sericin membranes. Prog. Biomater. 2, 1-10. doi: 10.1186/2194-0517-2-14

Christeller, J. T., Markwick, N. P., and Burgess, E. P. J. (1994). Midgut proteinase activities of three keratinolytic larvae, Hofmannophila pseudospretella, Tineola bisselliella, and Anthrenocerus australis, and the effect of proteinase inhibitors on proteolysis. Arch. Insect Biochem. Physiol. 25, 159-173. doi: 10.1002/arch.940250207

Coleman, A. D., Wouters, R. H. M., Mugford, S. T., and Hogenhout, S. A. (2015). Persistence and transgenerational effect of plant-mediated RNAi in aphids. J. Exp. Bot. 66, 541-548. doi: 10.1093/jxb/eru450

Crabtree, B., Higgins, S. J., and Newsholme, E. A. (1972). The activities of pyruvate carboxylase, phosphoenolpyruvate carboxylase and fructose diphosphatase in muscles from vertebrates and invertebrates. Biochem. J. 130, 391-396.

Cruz, J., Mane-Padros, D., Belles, X., and Martin, D. (2006). Functions of the ecdysone receptor isoform-A in the hemimetabolous insect Blattella germanica revealed by systemic RNAi in vivo. Dev. Biol. 297, 158-171. doi: 10.1016/j.ydbio.2006.06.048

Csikos, G., Molnar, K., Borhegyi, N. H., Talian, G. C., and Sass, M. (1999). Insect cuticle, an in vivo model of protein trafficking. J. Cell Sci. 112, 2113-2124.

Dong, Y., and Friedrich, M. (2005). Nymphal RNAi: systemic RNAi mediated gene knockdown in juvenile grasshopper. BMC Biotechnol. 3, 5-25. doi: $10.1186 / 1472-6750-5-25$

Duan, C. G., Wang, C. H., and Guo, H. S. (2012). Application of RNA silencing to plant disease resistance. Silence 3, 1-8. doi: 10.1186/1758-907X-3-5

Emmons, R. B., Duncan, D., Estes, P. A., Kiefel, P., Mosher, J. T., Sonnenfeld, M., et al. (1999). The spineless-aristapedia and tango bHLH-PAS proteins interact to control antennal and tarsal development in Drosophila. Development 126, 3937-3945.

Fellmann, C., and Lowe, S. W. (2014). Stable RNA interference rules for silencing, Nat. Cell Biol. 16, 10-18. doi: 10.1038/ncb2895

Ferguson, C., Lakey, A., Hutchings, A., Butcher, G. W., Leonard, K. R., and Bullard, B. (1994). Cytoskeletal proteins of insect muscle: location of zeelins in Lethocerus flight and leg muscle. J. Cell Sci. 107, 1115-1129.

Feyereisen, R. (1999). Insect P450 enzymes. Annu. Rev. Entomol. 44, 507-533. doi: 10.1146/annurev.ento.44.1.507

Firmino, A. A. P., Fonseca, F. C. dA., de Macedo, L. L. P., Coelho, R. R., and Antonino de Souza, J. D. Jr. (2013). Transcriptome analysis in cotton boll weevil (Anthonomus grandis) and RNA interference in insect pests. PLoS ONE 8:e85079. doi: 10.1371/journal.pone.0085079

Fischer, R., Ostafe, R., and Twyman, R. M. (2013). Cellulases from insects. $A d v$. Biochem. Eng. Biotechnol. 136, 51-64. doi: 10.1007/10_2013_206

Fraga, A., Ribeiro, L., Lobato, M., Santos, V., and Silva, J. R. (2013). Glycogen and glucose metabolism are essential for early embryonic development of the red flour beetle Tribolium castaneum. PLoS ONE 8:e65125. doi: 10.1371/journal.pone. 0065125

Gatehouse, J. A., and Price, D. R. G. (2011). "Protection of crops against insect pests using RNA interference," in Insect Biotechnology, ed A. Vilcinskas (Springer publications), 145-168.

Giannopoulos, N. G., Michalopoulos, I., Papandreou, N. C., Malatras, A., Iconomidou, V. A., and Hamodrakas, S. J. (2013). LepChorion.DB, a database of Lepidopteran chorion proteins and a set of tools useful for the identification of chorion proteins in Lepidopteran proteomes. Insect Biochem. Mol. Biol. 43, 189-196. doi: 10.1016/j.ibmb.2012.12.001

Gorbacheva, T. M., Syromyatnicov, M., Popov, V. N., Lopatin, A. V., Eprintsev, A. T., and Fedorin, D. N. (2013). Characteristics of functioning of succinate dehydrogenase from flight muscles of the bumblebee Bombus terrestris (L.). Biol. Bull. 40, 429-434. doi: 10.1134/S1062359013050051

Gordon, K. H. J., and Waterhouse, P. M. (2007). RNAi for insect-proof plants. Nat. Biotechnol. 25, 1231-1232. doi: 10.1038/nbt1107-1231

Gui, Z. Z., Lee, K. S., Kim, B. Y., Choi, Y. S., Wei, Y. D., Choo, Y. M., et al. (2006). Functional role of aspartic proteinase cathepsin D in insect Metamorphosis. BMC Dev. Biol. 6:49. doi: 10.1186/1471-213X-6-49

Gullan, P. J., and Cranston, P. S. (2010). The Insects: An Outline of Entomology. Wiley-Blackwell. Available online at: www.wiley.com/go/gullan/insects.

Gvakharia, B. O., Bebas, P., Cymborowski, B., and Giebultowicz, J. M. (2003). Disruption of sperm release from insect testes by cytochalasin and betaactin mRNA mediated interference. Cell. Mol. Life Sci. 60, 1744-1751. doi: 10.1007/s00018-003-3139-z

Hammond, S. M., Bernstein, E., Beach, D., and Havvon, G. J. (2000). An RNA directed nuclease mediates post-transcriptional gene silencing in Drosophila cells. Nature 404, 293-296. doi: 10.1038/35005107

Healy, J. A., Cross, T. F., and Healy, A. (2004). The alpha-Gpdh polymorphism in the tick Ixodes ricinus: similar diurnal trends in genotypic composition in Irish and Swedish population samples. Exp. Appl. Acarol. 32, 111-118. doi: 10.1023/B:APPA.0000018198.83551.72

Hensbergen, P. J., van Velzen, M. J., Nugroho, R. A., Donker, M. H., and van Straalen, N. M. (2000). Metallothionein-bound cadmium in the gut of the insect Orchesella cincta (Collembola) in relation to dietary cadmium exposure. Comp. Biochem. Physiol. C. Toxicol. Pharmacol. 125, 17-24. doi: 10.1016/S07428413(99)00087-0

Hess, C. R., McGuirl, M. M., and Klinman, J. P. (2008). Mechanism of the insect enzyme, tyramine beta monooxygenase, reveals differences from the mammalian enzyme, dopamine beta monooxygenase. J. Biol. Chem. 283, 3042-3049. doi: 10.1074/jbc.M705911200

Hetz, S. K., and Bradley, T. J. (2005). Insects breathe discontinuously to avoid oxygen toxicity. Nature 433, 516-519. doi: 10.1038/nature03106

Hoffmann, K. H., and Lorenz, M. W. (1998). Recent advances in hormones in insect pest control. Phytoparasitica 26, 323-330. doi: 10.1007/BF02981447

Hong-Hua, S. U., Gui-Rong,W., Yong-Jun, Z., Ge-Mei, L., and KongMing, W. U., Yu-Yuan, G. (2010). Screening of proteins interacting with Gq $\alpha$ by yeast two-hybrid technique in the antenna of Helicoverpa armigera (Lepidoptera: Noctuidae). Acta Entomol. Sinica 53, $1339-1344$.

Huang, Q., Deveraux, Q. L., Maeda, S., Salvesen, G. S., Stennicke, H. R., Hammock, B. D., et al. (2000). Evolutionary conservation of apoptosis mechanisms: lepidopteran and baculoviral inhibitor of apoptosis proteins are inhibitors of mammalian caspase-9. Proc. Natl. Acad. Sci. U.S.A. 97, 1427-1432. doi: $10.1073 /$ pnas.97.4.1427

Huvenne, H., and Smagghe, G. (2010). Mechanisms of dsRNA uptake in insects and potential of RNAi for pest control: a review. J. Insect Physiol. 56, 227-235 doi: 10.1016/j.jinsphys.2009.10.004

Insecticide Resistance Action Committee. (2014). Mode of Action Classification Scheme $v$ 7.3. Available online at: http://www.irac-online.org/documents/moaclassification/?ext=pdf

i5K Consortium. (2013). The i5K initiative: advancing arthropod genomics for knowledge, human health, agriculture, and the environment. J. Hered. 104, 595-600. doi: 10.1093/jhered/est050

Isaac, R. E., Ekbote, U., Coates, D., and Shirras, A. D. (1999). Insect angiotensinconverting enzyme. A processing enzyme with broad substrate specificity and a role in reproduction. Ann. N.Y. Acad. Sci. 897, 342-347. doi: 10.1111/j.17496632.1999.tb07904.x 
Jackson, A. L., Bartz, S. R., Schelter, J., Kobayashi, S. V., Burchard, J., Mao, M., et al. (2003). Expression profiling reveals off-target gene regulation by RNAi. Nat. Biotechnol. 21, 635-637. doi: 10.1038/nbt831

Johnson, N. F., and Triplehorn, C. A. (2005). Borror and DeLong's Introduction to the Study of Insects, 7th Edn. Thomson, Brooks/Cole.

Kennerdell, J. R., and Carthew, R. W. (1998). Use of dsRNA-mediated genetic interference to demonstrate that frizzled and frizzled 2 act in the wingless pathway. Cell 95, 1017-1026. doi: 10.1016/S0092-8674(00) 81725-0

Kitto, G. B., and Briggs, M. H. (1962). Lactate dehydrogenase in some insect muscles. Nature 193, 1003-1004. doi: 10.1038/1931003b0

Koch, A., and Kogel, K. H. (2014). New wind in the sails: improving the agronomic value of crop plants through RNAi-mediated gene silencing. Plant Biotechnol. J. 12, 821-831. doi: 10.1111/pbi.12226

Koiwa, H., Shade, R. E., Zhu-Salzman, K., D’Urzo, M. P., Murdock, L. L., Bressan, R. A., et al. (2000). A plant defensive cystatin (soyacystatin) targets cathepsin L-like digestive cysteine proteinases (DvCALs) in the larval midgut of western corn rootworm (Diabrotica virgifera virgifera). FEBS Lett. 471, 67-70. doi: 10.1016/S0014-5793(00)01368-5

Kotwica, J., Bebas, P., Gvakharia, B. O., and Giebultowicz, J. M. (2009). RNA interference of the period gene affects the rhythm of sperm release in moths. J. Biol. Rhythms 24, 25-34. doi: 10.1177/0748730408329109

Kumar, M., Gupta, G. P., and Rajam, M. V. (2009). Silencing of acetylcholinesterase gene of Helicoverpa armigera by siRNA affects larval growth and its life cycle. J. Insect Physiol. 55, 273-278. doi: 10.1016/j.jinsphys.2008.12.005

Kumar, P., Pandit, S. S., Steppuhn, A., and Baldwin, I. T. (2014). Natural historydriven, plant-mediated RNAi-based study reveals CYP6B46's role in a nicotinemediated antipredator herbivore defense. Proc. Natl. Acad. Sci. U.S.A. 111, 1245-1252. doi: 10.1073/pnas.1314848111

Lecroise, Y. A., Boulard, C., and Keil, B. (1979). Chemical and enzymatic characterization of the collagenase from the insect Hypoderma lineatur. Eur. J. Biochem. 101, 385-393. doi: 10.1111/j.1432-1033.1979.tb19730.x

Lehane, M., and Billingsley, P. (1996). Biology of the Insect Midgut (London: Chapman \& Hall), Republished online: Springer. doi: 10.1007/978-94-0091519-0

Lemoine, A., Millot, C., Curie, G., Massonneau, V., and Delachambre, J. (1993). Monoclonal antibodies recognizing larval- and pupal-specific cuticular proteins of Tenebrio molitor (Insecta, Coleoptera). Roux's Arch. Dev. Bio. 203, 92-99. doi: $10.1007 /$ BF00539894

Liu, S., Zhang, Y. R., Zhou, W. W., Liang, Q. M., Yuan, X., Cheng, J., et al. (2013). Identification and characterization of two sensory neuron membrane proteins from Cnaphalocrocis medinalis (Lepidoptera: Pyralidae). Arch. Insect Biochem. Physiol. 82, 29-42. doi: 10.1002/arch.21069

Liu, X., Li, J., Guo, W., Li, R., Zhao, D., and Li, X. (2014). A new type I peritrophic membrane protein from larval Holotrichia oblita (Coleoptera: Melolonthidae) binds to chitin. Int. J. Mol. Sci. 15, 6831-6842. doi: 10.3390/ijms15046831

Lorenzen, M. D., Brown, S. J., Denell, R. E., and Beeman, R. W. (2002). Cloning and characterization of the Tribolium castaneum eye-color genes encoding tryptophan oxygenase and kynurenine 3-monooxygenase. Genetics 160, 225-234.

Lu, M. X., Liu, Z. X., Cui, Y. D., and Du, Y. Z. (2014). Expression Patterns of Three heat shock proteins in Chilo suppressalis (Lepidoptera: Pyralidae). Ann. Entomol. Soc. Am. 107, 667-673. doi: 10.1603/AN13092

Lucas, W. J., Yoo, B. C., and Kragler, F. (2001). RNA as a longdistance information macromolecule in plants. Nat. Rev. Mol. Cell Biol. 2, 849-857. doi: $10.1038 / 35099096$

Lungchukiet, P., Donly, B. C., Zhang, J., Tobe, S. S., and Bendena, W. G. (2008). Molecular cloning and characterization of an allatostatin-like receptor in the cockroach Diploptera punctata. Peptides 29, 276-285. doi: 10.1016/j.peptides.2007.10.029

Lynch, J. A., and Desplan, C. (2006). A method for parental RNA interference in the wasp Nasonia vitripennis. Nat. Protoc. 1, 486-494. doi: 10.1038/nprot.2006.70

Maeda, I., Kohara, Y., Yamamoto, M., and Sugimoto, A. (2001). Large-scale analysis of gene function in Caenorhabditis elegans by high-throughput RNA. Curr. Biol. 11, 171-176. doi: 10.1016/S0960-9822(01)00052-5

Mangrauthia, S. K., Singh, P., and Praveen, S. (2010). Genomics of helper component proteinase reveals effective strategy for Papaya ringspot virus resistance. Mol. Biotechnol. 44, 22-29. doi: 10.1007/s12033-009-9205-5
Mao, Y. B., Cai, W. J., Wang, J. W., Hong, G. J., Tao, X. Y., Wang, L. J., et al. (2007). Silencing a cotton bollworm P450 monooxygenase gene by plant-mediated RNAi impairs larval tolerance of gossypol. Nat. Biotechnol. 25, 1307-1313. doi: $10.1038 /$ nbt1352

McGavin, G. C. (2001). Essential Entomology: An Order-by-Order Introduction. Oxford: Oxford University Press.

Misquitta, L., and Paterson, B. M. (1999). Targeted disruption of gene function in Drosophila by RNA interference (RNA-i): a role for nautilus in embryonic somatic muscle formation. Proc. Natl. Acad. Sci. U.S.A. 96, 1451-1456. doi: 10.1073/pnas.96.4.1451

Moriyama, Y., Sakamoto, T., Karpova, S. G., Matsumoto, A., Noji, S., and Tomioka, K. (2008). RNA interference of the clock gene period disrupts circadian rhythms in the cricket Gryllus bimaculatus. J. Biol. Rhythms 23, 308-318. doi: 10.1177/0748730408320486

Mutti, N. S., Park, Y., Reese, J. C., and Reeck, G. R. (2006). RNAi knockdown of a salivary transcript leading to lethality in the pea aphid, Acyrthosiphon pisum. J. Insect Sci. 6, 1-7. doi: 10.1673/031.006.3801

Nakayashiki, H., and Nguyen, Q. B. (2008). RNA interference: roles in fungal biology. Curr. Opin. Microbiol. 11, 494-502. doi: 10.1016/j.mib.2008.10.001

Nauen, R., and Bretschneider, T. (2002). New modes of action of insecticides. Pestic. Outlook 13, 241-245. doi: 10.1039/b211171n

Nauen, R., and Denholm, I. (2005). Resistance of insect pests to neonicotinoid insecticides:current status and future prospects. Arch. Insect Biochem. Physiol. 58, 200-215. doi: 10.1002/arch.20043

Neuman-Silberberg, F. S., and Schüpbach, T. (1996). The Drosophila TGFalpha-like protein Gurken: expression and cellular localization during Drosophila oogenesis. Mech. Dev. 59, 105-113. doi: 10.1016/0925-4773(96) 00567-9

Odman-Naresh, J., Duevel, M., Muthukrishnan, S., and Merzendorfer, H. (2013). A lepidopteran-specific gene family encoding valine-rich midgut proteins. PLoS ONE 8:e82015. doi: 10.1371/journal.pone.0082015

Pitino, M., Coleman, A., Maffei, M., Ridout, C., and Hogenhout, S. (2011). Silencing of aphid genes by dsRNA feeding from plants. PLoS ONE 6:e25709. doi: 10.1371/journal.pone.0025709

Praveen, S., and Mangrauthia, S. K. (2006). Viral suppressors: small RNA regulators. Indian J. Virol. 17, 67-77.

Price, D. R. G., and Gatehouse, J. A. (2008). RNAi mediated crop protection against insects. Trends Biotechnol. 26, 393-400. doi: 10.1016/j.tibtech.2008. 04.004

Rajagopal, R., Sivakumar, S., Agrawal, N., Malhotra, P., and Bhatnagar, R. K. (2002). Silencing of midgut aminopeptidase $\mathrm{N}$ of Spodoptera litura by double-stranded RNA establishes its role as Bacillus thuringiensis toxin receptor. J. Biol. Chem. 277, 46849-46851. doi: 10.1074/jbc.C200 523200

Reiko, I., and Ashida, M. (1986). Biosynthesis of prophenoloxidase in hemocytes of larval hemolymph of the silkworms, Bombyx mori. Insect Biochem. 16, 547-555. doi: 10.1016/0020-1790(86)90032-6

Rogers, M. E., Krieger, J., and Vogt, R. G. (2001). Antennal SNMPs (sensory neuron membrane proteins) of Lepidoptera define a unique family of invertebrate CD36-like proteins. J. Neurobiol. 49, 47-61. doi: 10.1002/neu.1065

Ruiz-Medrano, R., Xoconostle-Cázares, B., and Lucas, W. J. (1999). Phloem long-distance transport of CmNACP mRNA: implications for supracellular regulation in plants. Development 126, 4405-4419.

Schoofs, L., Clynen, E., and Salzet, M. (2002). Trypsin and chymotrypsin inhibitors in insects and gut leeches. Curr. Pharm. Des. 8, 483-491. doi: $10.2174 / 1381612023395718$

Schwab, R., Ossowski, S., Riester, M., Warthmann, N., and Weigel, D. (2006). Highly specific gene silencing by artificial microRNAs in Arabidopsis. Plant Cell 18, 1121-1133. doi: $10.1105 /$ tpc. 105.039834

Scott, J. G., Michel, K., Bartholomay, L. C., Siegfried, B. D., Hunter, W. B., Smagghe, G., et al. (2013). Towards the elements of successful insect RNAi. J. Insect Physiol. 59, 1212-1221. doi: 10.1016/j.jinsphys.2013.08.014

Senthil-Kumar, M., and Mysore, K. S. (2011). "Caveat of RNAi in plants: the offtarget effect," in RNAi and Plant Gene Function Analysis, Methods in Molecular Biology, eds H. Kodama and A. Komamine, (Netherland: Springer) 744.

Shabalina, S. A., and Koonin, E. V. (2008). Origins and evolution of eukaryotic RNA interference. Trends Ecol. Evol. 23, 578-587. doi: 10.1016/j.tree.2008.06.005 
Shappirio, D. G. (1974). Comparative studies of oxidative enzyme systems in epidermis and fat body of diapausing and non-diapausing silkmoths. J. Insect Physiol. 20, 291-300. doi: 10.1016/0022-1910(74)90061-4

Shinoda, T., and Itoyama, K. (2003). Juvenile hormone acid methyltransferase: a key regulatory enzyme for insect metamorphosis. Proc. Natl. Acad. Sci. U.S.A. 100, 11986-11991. doi: 10.1073/pnas.2134232100

Shu, Y. H., Wang, J. W., Lu, K., Zhou, J. L., Zhou, Q., and Zhang, G. R. (2011). The first vitellogenin receptor from a Lepidopteran insect: molecular characterization, expression patterns and RNA interference analysis. Insect Mol. Biol. 20, 61-73. doi: 10.1111/j.1365-2583.2010.01054.x

Sim, C., and Denlinger, D. L. (2011). Catalase and superoxide dismutase- 2 enhance survival and protect ovaries during overwintering diapause in the mosquito Culex pipiens. J. Insect Physiol. 57, 628-634. doi: 10.1016/j.jinsphys.2011. 01.012

Sivakumar, S., Rajagopal, R., Venkatesh, G. R., Srivastava, A., and Bhatnagar, R. K. (2007). Knockdown of aminopeptidase- $\mathrm{N}$ from Helicoverpa armigera larvae and in transfected Sf21 Cells by RNA interference reveals its functional interaction with Bacillus thuringiensis insecticidal protein crylac. J. Biol. Chem. 282, 7312-7319. doi: 10.1074/jbc.M607442200

Sparagana, S. P., Bhaskaran, G., and Barrera, P. (1985). Juvenile hormone acid methyltransferase activity in imaginal discs of Manduca sexta prepupae. Arch. Insect Biochem. Physiol. 2, 191-202. doi: 10.1002/arch.9400 20207

Spring, J. H., Robichaux, S. R., and Hamlin, J. A. (2009). The role of aquaporins in excretion in insects. J. Exp. Biol. 212, 358-362. doi: 10.1242/jeb.024794

Steele, J. E. (1982). Glycogen phosphorylase in insects. Insect Biochem. 12, 131 -147. doi: 10.1016/0020-1790(82)90001-4

Strickler-Dinglasan, P. M., Guz, N., Attardo, G., and Aksoy, S. (2006). Molecular characterization of iron binding proteins from Glossina morsitans morsitans (Diptera: Glossinidae). Insect Biochem. Mol. Biol. 36, 921-933. doi: 10.1016/j.ibmb.2006.09.003

Suiter, D. R., and Scharf, M. E. (2011). Insecticide Basics for the Pest Management Professional. Univ. Ga. Bull. 1352, 1-24.

Suzuki, Y., Truman, J. W., and Riddiford, L. M. (2008). The role of Broad in the development of Tribolium castaneum: implications for the evolution of the holometabolous insect pupa. Development 135, 569-577. doi: 10.1242/dev.015263

Swingle, H. S. (1925). Digestive enzymes of an insect. Ohio J. Sci. 25, 209-218. Available online at: http://hdl.handle.net/1811/2281.

Tabara, H., Grishok, A., and Mello, C. C. (1998). RNAi in C. elegans: soaking in the genome sequence. Science 282, 430-431. doi: 10.1126/science.282.5388.430

Tang, B., Wang, S., and Zhang, F. (2010). Two storage hexamerins from the beet armyworm Spodoptera exigua: cloning, characterization and the effect of gene silencing on survival. BMC Mol. Biol. 11:65. doi: 10.1186/1471-2199-11-65

Tang, B., Xu, Q., Zou, Q., Fang, Q., Wang, S., and Ye, G. (2012). Sequencing and characterization of glycogen synthase and glycogen phosphorylase genes from Spodoptera exigua and analysis of their function in starvation and excessive sugar intake. Arch. Insect Biochem. Physiol. 80, 42-62. doi: 10.1002/arch.21027

Thakur, N., Upadhyay, S., Verma, P., Chandrashekar, K., Tuli, R., and Singh, P. K. (2014). Enhanced whitefly resistance in transgenic tobacco plants expressing double stranded RNA of v-ATPaseA Gene. PLoS ONE 9:e87235. doi: 10.1371/journal.pone. 0087235

Thany, S. H., Leignel, T. H., and Lapied, B. (2010). Identification of cholinergic synaptic transmission in the insect nervous system. Adv. Exp. Med. Biol. 683, 1-10. doi: 10.1007/978-1-4419-6445-8_1

Timmons, L., and Fire, A. (1998). Specific interference by ingested dsRNA. Nature 395, 854. doi: $10.1038 / 27579$

Tomari, Y., and Zamore, P. O. (2005). Perspective: machines for RNAi. Genes Dev. 19, 517-529. doi: 10.1101/gad.1284105

Tomoyasu, Y., Miller, S. C., Tomita, S., Schoppmeier, M., Grossmann, D., and Bucher, G. (2008). Exploring systemic RNA interference in insects: a genomewide survey for RNAi genes in Tribolium. Genome Biol. 9, R10. doi: 10.1186/gb2008-9-1-r10

Turner, C. T., Davy, M. W., MacDiarmid, R. M., Plummer, K. M., Birch, N. P., and Newcomb, R. D. (2006). RNA interference in the light brown apple moth, Epiphyas postvittana (Walker) induced by double-stranded RNA feeding. Insect Mol. Biol. 15, 383-391. doi: 10.1111/j.1365-2583.2006. 00656.x
Upadhyay, S. K., Chandrashekar, K., Thakur, N., Verma, P. C., Borgio, J. F., Singh, P. K., et al. (2011). RNA interference for the control of whiteflies (Bemisia tabaci) by oral route. J. Biosci. 36, 153-161. doi: 10.1007/s12038-011-9009-1

Vaucheret, H. (2006). Post-transcriptional small RNA pathways in plants: mechanisms and regulations. Genes Dev. 20, 759-771. doi: 10.1101/gad.1410506

Walker, W. B., and Allen, M. L. (2010). Expression and RNA interference of salivary polygalacturonase genes in the tarnished plant bug, Lygus lineolaris. J. Insect Sci. 10, doi: 10.1673/031.010.14133

Wang, S., Conant, G. C., Ou, R., and Beerntsen, B. T. (2012). Cloning and characterization of the peptidoglycan recognition protein genes in the mosquito, Armigeres subalbatus (Diptera: Culicidae). J. Med. Entomol. 49, 656-671. doi: 10.1603/ME11165

Wang, Z., Dong, Y., Desneux, N., and Niu, C. (2013). RNAi silencing of the HaHMG-CoA reductase gene inhibits oviposition in the Helicoverpa armigera cotton bollworm. PLoS ONE 8:e67732 doi: 10.1371/journal.pone.00 67732

Wani, S. H., Sanghera, G. S., and Singh, G. S. (2010). Biotechnology and plant disease control-role of RNA interference. Am. J. Plant Sci. 1, 55-68. doi: 10.4236/ajps.2010.12008

Warthmann, N., Chen, H., Ossowski, S., Weigel, D., and Herve, P. (2008). Highly specific gene silencing by artificial miRNAs in rice. PLOS ONE 3, 1-10. doi: 10.1371/journal.pone.0001829

Waterhouse, P. M., and Helliwell, C. A. (2003). Exploring plant genomes by RNA-induced gene silencing. Nat. Rev. Genet. 4, 29-38. doi: 10.1038/nrg982

Wing, K. D., Schnee, M. E., Sacher, M., and Connair, M. (1998). A novel oxadiazine insecticide is bioactivated in lepidopteran larvae. Arch. Insect Biochem. Physiol. 3, 91-103.

Winston, W. M., Molodowitch, C., and Hunter, C. P. (2002). Systemic RNAi in C. elegans requires the putative transmembrane protein SID-1. Science 295, 2456-2459. doi: 10.1126/science. 1068836

Xiong, Y., Zeng, H., Zhang, Y., Xu, D., and Qiu, D. (2013). Silencing the HaHR3 gene by transgenic plant-mediated RNAi to disrupt Helicoverpa armigera development. Int. J. Biol. Sci. 9, 370-381. doi: 10.7150/ijbs.5929

Xu, P., Zhang, Y., Kang, L., Roossinck, M. J., and Mysore, K. S. (2006). Computational estimation and experimental verification of off-target silencing during posttranscriptional gene silencing in plants. Plant Physiol. 142, 429-440. doi: 10.1104/pp.106.083295

Xu, X., Jin, F., Yu, X., Ji, S., Wang, J., Cheng, H., et al. (2007). Expression and purification of a recombinant antibacterial peptide, cecropin, from Escherichia coli. Protein Expr. Purif. 53, 293-301. doi: 10.1016/j.pep.2006.12.020

$\mathrm{Xu}, \mathrm{Y}$., Zou, Z., Zha, X., Xiang, Z., and He, N. (2012). A syntenic coding region for vitelline membrane proteins in four lepidopteran insects. J. Mol. Biochem. $1,155-160$.

Yan, J., Cheng, Q., Li, C. B., and Aksoy, S. (2001). Molecular characterization of two serine proteases expressed in gut tissue of the African trypanosome vector, Glossina morsitans morsitans. Insect Mol. Biol. 10, 47-56. doi: 10.1046/j.13652583.2001.00232.x

Yang, Z., Chen, J., Chen, Y., and Jiang, S. (2010). Molecular cloning and characterization of an acetylcholinesterase cDNA in the brown planthopper, Nilaparvata lugens. J. Insect Sci. 10, 102. doi: 10.1673/031.010.10201

Yao, J., Rotenberg, D., Afsharifar, A., Barandoc-Alviar, K., and Whitfield, A. E. (2013). Development of RNAi Methods for Peregrinus maidis, the Corn Planthopper. PLoS ONE 8:e70243. doi: 10.1371/journal.pone.0070243

Yin, J., Feng, H., Sun, H., Xi, J., Cao, Y., and Li, K. (2012). Functional analysis of general odorant binding protein 2 from the meadow moth, Loxostege sticticalis L. (Lepidoptera: Pyralidae). PLoS ONE 7:e33589. doi: 10.1371/journal.pone. 0033589

Yokoyama, H., Yokoyama, T., Yuasa, M., Fujimoto, H., Sakudoh, T., Honda, N., et al. (2013). Lipid transfer particle from the silkworm, Bombyx mori, is a novel member of the apoB/large lipid transfer protein family. J. Lipid Res. 54, 2379-2390. doi: 10.1194/jlr.M037093

You-Jin, H., Wen-Xia, H. U., and Bin, C. (2014). Comparative analysis of proteins in non-and summer-diapausing pupae of the onion fly, Delia antiqua (Diptera: Anthomyiidae), using two-dimensional gel electrophoresis. Acta Entomol. Sinica 57, 161-167.

Yu, N., Christiaens, C., Liu, J., Niu, J., Cappelle, K., Caccia, S., et al. (2013). Delivery of dsRNA for RNAi in insects: an overview and future directions. Insect Sci. 20, 4-14. doi: 10.1111/j.1744-7917.2012.01534.x 
Zalewska, M., Kochman, A., Estève, J. P., Lopez, F., Chaoui, K., Susini, C., et al. (2009). Juvenile hormone binding protein traffic-Interaction with ATP synthase and lipid transfer proteins. Biochim. Biophys. Acta 1788, 1695-1705. doi: 10.1016/j.bbamem.2009.04.022

Zamore, P. D., Tuschl, T., Shorp, P. A., and Bartel, D. P. (2000). RNAi: double stranded RNA directs the ATP-dependent cleavage of mRNA at 21 to 23 nucleotide intervals. Cell 101, 25-33. doi: 10.1016/S0092-8674(00) 80620-0

Zha, W., Peng, X., Chen, R., Du, B., and Zhu, L. (2011). Knockdown of midgut genes by dsRNA-transgenic plant-mediated RNA interference in the hemipteran insect Nilaparvata lugens. PLoS ONE 6:e20504. doi: 10.1371/journal.pone.0020504

Zhang, H., Li, H. C., and Miao, X. X. (2013b). Feasibility, limitation and possible solutions of RNAi-based technology for insect pest control. Insect Sci. 20, 15-30. doi: 10.1111/j.1744-7917.2012.01513.x

Zhang, J., Li, D., Ge, P., Guo, Y., and Zhu, K. Y. (2014). Molecular and functional characterization of cDNAs putatively encoding carboxylesterases from the migratory locust, Locusta migratoria. PLoS ONE 9:e94809. doi: 10.1371/journal.pone.0094809

Zhang, X., Liu, X., Ma, J., and Zhao, J. (2013a). Silencing of cytochrome P450 CYP6B6 gene of cotton bollworm (Helicoverpa armigera) by RNAi. Bull. Entomol. Res. 103, 584-591. doi: 10.1017/S00074853130 00151

Zhao, H., Yi, X., Hu, Z., Hu, M., and Chen, S. (2013). RNAi-mediated knockdown of catalase causes cell cycle arrest in SL-1 cells and results in low survival rate of Spodoptera litura (Fabricius). PLoS ONE 8:e59527. doi: 10.1371/journal.pone.0059527

Zhao, Y., Yang, G., Wang-Pruski, G., and You, M. (2008). Phyllotreta striolata (Coleoptera: Chrysomelidae): Arginine kinase cloning and RNAibased pest control. Eur J. Entomol. 105, 815-822. doi: 10.14411/eje. 2008.108

Zhu, F., Sams, S., Moural, T., Haynes, K. F., Potter, M. F., and Palli, S. R. (2012). RNA interference of NADPH-cytochrome $\mathrm{P} 450$ reductase results in reduced insecticide resistance in the bed bug, Cimex lectularius. PLoS ONE 7:e31037. doi: 10.1371/journal.pone.0031037

Zhu, Q., Arakane, Y., Beeman, R. W., Kramer, K. J., and Muthukrishnan, S. (2008). Functional specialization among insect chitinase family genes revealed by RNA interference. Proc. Natl. Acad. Sci. U.S.A. 105, 6650-6655. doi: $10.1073 /$ pnas.0800739105

Conflict of Interest Statement: The authors declare that the research was conducted in the absence of any commercial or financial relationships that could be construed as a potential conflict of interest.

Copyright (c) 2015 Kola, Renuka, Madhav and Mangrauthia. This is an open-access article distributed under the terms of the Creative Commons Attribution License (CC $B Y)$. The use, distribution or reproduction in other forums is permitted, provided the original author(s) or licensor are credited and that the original publication in this journal is cited, in accordance with accepted academic practice. No use, distribution or reproduction is permitted which does not comply with these terms. 